\title{
SUJETO CON PREPOSICIÓN EN ESPAÑOL Y CUESTIONES CONEXAS*
}

1. La preposición, como clase lingüística, es un elemento que señala la relación existente entre otros elementos de la oración (normalmente dos), según la opinión más aceptada por los lingüistas. No tiene, pues, valor autónomo, ni puede emplearse de forma independiente; su función es la de servir de enlace entre otros constituyentes oracionales, marcando la dependencia sintáctica del constituyente que introduce respecto del otro. Hay que analizarla, por tanto, como marca de la rección establecida entre un término principal, o regente, y otro subordinado, o regido, y como índice del tipo de función sintáctica que cumple el elemento introducido por ella. En este sentido, puede definirse como 'monema funcional' o 'indicador de función' ', como 'subordinante' $^{2}$, e, incluso, como 'morfema con función hipotáctica' ${ }^{3}$ : su puesto estaría entre las categorías de morfemas, perteneciendo, junto con el

- Agradezco a D. Rafael Lapesa las sugerencias que me hizo para este trabajo, así como su extraordinaria amabilidad al poner a mi disposición los ficheros del Seminario de Lexicografía de la R. A. E.

1 A. Martinet, Elementos de lingüistica general (versión española de Julıo CALONGE), 2.a ed., Madrid, Ed. Gredos, 1970, $\$ \$ 4.12$ y 4.46.

2 ANA M.a BARRRnechi, «Las clases de palabras en español como clases funcionales», en Estudios de gramática estructural, Buenos Aires, Ed. Paidós, 1969, páginas 9-26.

3 R. Trujinlo, «Notas para un estudio de las preposiciones españolas», en Thesavrvs. Boletín del Instituto Caro y Cuervo, t. XXVI, 1971, págs. 234279. 
artículo, al grupo de morfemas «independientes», es decir, sin puesto fijo en la palabra 4 .

Sin embargo, el problema de la clasificación lingüística de la preposición (si es, p. ej., una 'parte de la oración' o no), así como sus relaciones con otras clases, no puede darse todavía por definitivamente resuelto. Pero creemos que la caracterización anterior como elemento indicador de función puede considerarse válida, y preferible, en una lengua como el español, que carece de morfemas casuales, a la ofrecida por Hjelmslev, quien definía a la preposición como plerema que rige un morfema nominal, el 'caso's. Como en tantos otros ámbitos de la Lingüística, las teorías sobre la preposición han sido, y son, muy variadas e incluso contradictorias en ocasiones ${ }^{6}$.

Por todo ello, se explica que ciertos empleos de las preposiciones hayan desconcertado a veces a los gramáticos: concretamente, su presencia ante sintagmas nominales, o analizables como tales, que realizan la función de sujeto, función que no suele considerarse 'subordinada' ?, y que, tanto en español como en la mayoría de las lenguas, no va señalada por ningún 'índice funcional' del tipo de la preposición. Sin embargo, éste no es un hecho aislado, y no puede separarse de otros donde tampoco puede considerarse a la preposición en su función habitual. Todo esto obliga a replantear, por un lado, el valor funcional de esos elementos, normalmente 'preposiciones', en tales contextos, y por otro, la relación entre las preposiciones y otras categorías lingüísticas, así como una posible re-definición de éstas.

En lo que sigue, se analizarán estos empleos de algunas preposiciones españolas (p. ej., según, entre, hasta, etc.), y su relación con la función de elementos cuya clasificación nunca ha sido muy clara (aun, incluso, salvo, etc.), con el objetivo de asignarles un 'status' categorial definido. El análisis será histórico, para intentar llegar a conclusiones sobre su valor sincrónico en español actual.

4 Para Coseriu la preposición es 'palabra morfemática'; véase, p. ej., «Semántica y gramática», págs. 133-134 (en Gramática, semántica, universales, Madrid, Ed. Gredos, 1978).

5 Cfr. Principios de gramática general, Madrid, Ed. Gredos, 1976 (versión espanola de Frurx PINERo), págs. 145 y sigs.; «La noción de rección» (en Ensayos lingüísticos (versión española de Elena BombfN y Félix PrNero), Madrid, Ed. Gredos, 1972), págs. 188 y sigs.

6 Un resumen bastante completo puede verse en M.a LUISA LOPEZ, Problemas $y$ métodos en el análisis de preposiciones, Madrid, Ed. Gredos, 1972, págs. 12-86.

7 Para una de las pocas opiniones en contra, véase L. TBSNikRE, Eléments de syntaxe structurale, 2.e éd., Paris, Librairie Klincsieck, 1966, págs. 102 y sigs. 
2. La preposición según ha tenido casi siempre una consideración especial dentro del inventario tradicional de preposiciones españolas. Su rasgo más llamativo es que, frente a todas las demás, lleva siempre acento, incluso en la grafía ${ }^{8}$; además, se combina con las formas pronominales de nominativo. Por ello, Trujillo la considera preposición «imperfectan, o preposición no de lengua; está aislada dentro del conjunto de relaciones semánticas cubiertas por las preposiciones: su valor nocional de 'conformidad' hace que no establezca oposición directa con ninguna otra (no obstante, la incluye dentro del subsistema 'estático', y entre aquellas cuyo rasgo es la 'no-orientación de la situación': en, entre, con, sin). Por su parte, M.. Luisa López ${ }^{9}$ la agrupa junto a contra: sólo se oponen en el campo 'nocional', donde contra indica 'oposición' y según 'acompañamiento' (preferimos el término de 'conformidad'). Sin embargo, no siempre aparecen en los mismos contextos, en oposición mutua: «según Juan, mañana lloverá" / ?«-contra Juan, mañana lloverá» ${ }^{10}$. Y hay matices de según donde no cabe la oposición con contra: «según la cara que trae, no parece muy alegre» (significado de 'a juzgar por, atendiendo a', que surge de su valor básico de 'conformidad').

2.1. Según no conservó en español los valores espaciales ('a lo largo de') o temporales ('(inmediatamente) después') que tenía secundum en latín, a partir de su empleo arcaico como adverbio (con el significado de 'siguiendo, detrás'). Como preposición, desarrolló en español sólo los matices del valor nocional de 'conformidad' ". No aparece en el Poema del Cid, pero es ya frecuente desde el siglo xIII con los valores que tiene todavía en castellano. Así, con sentido de conformidad con norma $\mathrm{u}$ orden superior, costumbre, etc.:

"E esta uendida es fecha secundo la costumpne de Toledo» (Doc. Ling., n.o 265, Toledo, 1206), "Vivién segund la regla en toda onestad» (Berceo, Milagros, $506 \mathrm{~d}$ ), «...judgar derechamente sin parçialidad alguna segunt las reglas del artew (Villena, Arte de Trovar, en Crestom., 557.28-29), etc;

8 T. NAvarro TOMAs, Manual de pronunciación española, 13.a ed., CSIC, Madrid, 1965, § 170 a.

9 Op. cit., pág. 144.

10 No obstante, en tratados doctrinales, y quizás como herencia del lenguaje escolástico, puede encontrarse: "Contra Aristóteles, no se puede afirmar la identidad de categorías lógicas y lingüísticas”; esa oposición, pues, podría darse en un tipo restringido de enunciados.

11 Tampoco mantuvo el sentido de 'en provecho de' que presentaba, p. ej., en la expresión jurídica «iudicare secundum aliquem»; cfr. O. RIEMAN, Syntaxe latine, 7. éd. revue par A. ERnoUt, Paris, Librairie Klincksieck, 1942, § 120. 
con este valor es normal, en la lengua medieval y clásica sobre todo, que el sustantivo aparezca sin actualizador en expresiones quizás fijadas por imitación del latín:

"quieren segund natura conpañía sienpre nueva» (JRuiz, LBA, $127 \mathrm{~d}$ ), «si ellos dizen que passo en verdad, creerlo he segun derechow (Celestina, XIII), «Que Portugal es tuyo, en quien sucedes, / según ley, por razón hereditaria» (Lope, Lealtad en el agravio, apud C. Fernández, Vocabulario completo de Lope de Vega, RAE, 1971).

Indicando conformidad o concordancia de lo expresado en la oración con opiniones, enunciados, etc. de alguien, el sustantivo introducido por según suele ser abstracto, o resultado de la nominalización de un verbo, incluido en el área de 'pensar' o 'decir' (y el contenido de ese pensamiento o enunciación es la oración):

«según mi opinión, esto no es así» (= «opino que esto no es asín); «Ca non es en est mundo secund el mi creer» (Berceo, Milagros, 645 b), etc.

Con este valor es muy frecuente que el término introducido por según sea un neutro, seguido a veces por un relativo:

«Domingo fue de mannana segunt lo que leemos» (Berceo, Loores, $103 \mathrm{~d}$ ), "pleito que en la primera vista, segund lo que yo puedo entender* (DJManuel, Lucanor, Enx. V), etc.;

y también aparece ante sustantivos sin actualizador:

"...y sobrino (según fama) de fray Francisco Giménez» (DHurtado de Mendoza, Guerra, II), "y haremos el potable, que es desta suerte, segun dotrina de Leon Suauio» (Lope, Dorotea, 13)

(hoy pervive cuando el sustantivo va en plural o lleva un adjetivo: "según confesión propia», "según opiniones ajenas», etc.). Y aparece también en el siglo xIII señalando la correspondencia, relación, dependencia, etc. de una cosa respecto de otra:

«Et los salarios delos maestros deuen ser establesçidos (...) cada vno quanto aya, segunt la çiençia quel mostrare o segunt que fuere sabidor della» (Partidas, tit. XXX, ley III), etc.;

con este valor, a veces el sustantivo que introduce puede ir también sin actualizador: "se paga según cosecha» (recogido en el habla rural de Osuna).

En suma, los valores fundamentales de seguin estaban ya fijados en las primeras épocas del idioma. En ese valor básico de 'conformidad' o 'adecuación' expresado por esta preposición late un claro sentido 
modal, que ya presentaba su antecedente latina ${ }^{12}$. En ocasiones, ese sentido puede parafrasearse por una expresión con como: «vivir según la regla» = "vivir como ordena la regla». Es en este contexto, a partir del valor de relación o dependencia señalado arriba, y próximo a construcciones comparativo-modales con como, donde encontramos el primer caso de según con forma pronominal de sujeto, aunque no en tal función:

"...lo cual yo no niego, pero atrevíme a ello pensando que me harías merced no segund quien la pedía, mas segund tú que la haviés de dar» (D. de SPedro, Cárcel de Amor, 151).

El valor semántico, y por tanto la función sintáctica, es el mismo que en otros contextos donde se analiza inequívocamente como preposición; la presencia de tú puede justificarse: a) por la contraposición con la frase anterior donde introduce al relativo sujeto (pero: «...no para quien lo pedía sino para ti», etc.); b) proximidad significativa a como (sentido de "como corresponde a», "como es propio de», etc.), y por tanto extensión del tipo de sintagma como yo, como tú; c) proceso elíptico a partir de frases como según eres tú, etc., donde la antigua preposición se ha convertido en un elemento introductor de oraciones («adverbio conjuntivo modal» lo llama la gramática), basado, precisamente, en la analogía con como.

Ese valor modal, con o sin otros matices concomitantes, es el que encontramos en muchos complementos introducidos por según, especialmente en la lengua medieval, y es lo que, a nuestro juicio, constituye la base que explica las peculiaridades sintácticas de esta preposición:

«...pues todas las cosas que uos dixieren guardat e fazet, mas no fagades segund las obras dellos» (Biblia med. rom., IV, Mat., XXIII), «Ca la su vida deve ser seca e arida o arenosa, segunt la tierra de Libia» (Villena, Doze trabajos, 4.0), "De espinas trahen los velos (...) segund donzellas d'estado» (Santillana, Cantar a sus hijas, 2): matiz de "como corresponde a"; "o sy an de ser segund los angeles que cayeron, o segund los que quedaron" (Martín Alfonso de Córdoba, Tractado de la predestinación, Introd.);

también entra en correlaciones comparativas, donde puede suponerse desde luego la elisión de un verbo ser, pero que es otra muestra de sus cruces con como:

12 Obsérvese la traducción: «Todas las cosas ser criadas a manera de contienda o batalla, dize aquel gran sabio Eraclio en el modo: Omnia secundum litem fiunt» (Celestina, Prólogo). 
«Segunt el poder suyo, / tanto es la obra suya; / segunt el poder tuyo, / tal es la obra tuyax (Don Sem Tob, Proverbios, 23).

Esa analogía semántica que conduce a una analogía sintáctica se muestra finalmente en el empleo de según introduciendo elementos predicativos referidos al sujeto en general, y que se produce con cierta frecuencia en la época medieval:

«...que no es negro ni bermeio, mas toma parte de ambas colores segund castanna» (Libro Caballos, en Crestom., 253.4), «castellanos aguardando / al muy noble rrey de España, / que yua en aquel dia / segund rrey de grand bondat” (Poema Alfonso XI, 1553 b-c-1554 a-b), «Yo hize lo que devía segund piadosa, y tengo lo que merezco segund desdichada (Diego de SPedro, Cárcel, 127), «...y ordenes en lo que agora estás no segund sañudo, mas segund sabidor" (ibid., 131).

Como vemos, el sentido es muy próximo al que presenta como en los mismos contextos ${ }^{13}$; con ello, según se une a las preposiciones de o por, que pueden introducir también predicativos referidos al sujeto 0 al objeto directo. La función de predicativo (como otras: complementos locativos, temporales, etc.) no necesita ir introducida siempre por preposición; pero éstas son necesarias para indicar ciertos valores, o con ciertos verbos o nombres que, de otro modo, no podrían integrar tal esquema. Creemos que éste es el valor funcional que tiene como en tales contextos: el de preposición ${ }^{14}$, ya que indica la función del ele. mento que sigue, a la vez que aporta un contenido semántico determinado.

Otro de los valores fundamentales de según es el de introducir a un sustantivo que indica una fuente de información : persona, corriente

13 Cfr. R. LAPBSA, «Sintaxis histórica del adjetivo calificativo no atributivo», en Homenaje al Instituto de Filología «Dr. Amado Alonso», 1975, págs. 171-199, especialmente pág. 189.

14 Sin embargo, las posibilidades funcionales de como son muy complejas: a partir de su primitivo valor de adverbio relativo («el modo como lo hizo»), y casi siempre sobre un valor modal, lo encontramos en la comparación ( «es tan bueno como túx), donde podría considerarse conjunción de acuerdo con lo que dice Alarcos para que en Estudios de gramática funcional del español, Madrid, Editorial Gredos, 1970, págs. 204206; ese valor conjuntivo lo sefiala A. BeLLo, Gramática de la lengua castellana, 9.a ed., Buenos Aires, Ed. Sopena, 1973, §§ 1234-1235, cuando enlaza elementos análogos: «trabaja como su padre» (con dos sentidos: «trabaja del mismo modo que su padre» / «trabaja, y su padre también lo hacew), siendo posible que uno esté elidido: "trabaja como nunca»; y es preposición cuando introduce predicados, ya que ahí no parece reproducir un elemento análogo: sin embargo, para Alarcos, es elemento 'prepositivo' tanto en este caso como en el anterior: cfr. op. cit., pág. 230. De todas formas, como necesita un análisis propio a fondo. 
de opinión, obra, etc., de donde surge lo que se dice en la frase; es decir, «según Juan, esto no es así» puede parafrasearse por «en conformidad con lo que dice Juan...» o "Juan dice que...»: lo enunciado no aparece como afirmación del que habla, sino que se atribuye a otro, y se puede estar de acuerdo o no. En principio, era un tipo de construcción que se daba sobre todo en el lenguaje doctrinal: con nombres propios de evangelistas se documenta ya secundum en el siglo IV, traduciendo al griego koróx, y es muy frecuente en citas ${ }^{15}$. Su vía de transmisión parece que fue el latín escolástico, como muestran los testimonios castellanos medievales:

«Ca avnque a Çiçeron todos los latinos reconoscen el primado de eloquençia, mas segund el mundo fablo en muchos logares...» (Alonso de Cartagena, Traducciones de Séneca, en Crestom., 571.43-44), «...en la qual nasce el cuerpo segun algunos philosophos. Segund nos es la voluntad de Dios» (R. Fdez. Santaella, Vocabulario eclesiástico, s. v. Fatu).

Posteriormente, se ha generalizado, aunque siempre con mayor frecuencia de uso en el tipo de lenguaje señalado, dada la continua referencia a autores y citas que es propia de él:

«...lugar alto y empinado, según la autoridad de Ducange» (Jovellanos, Obras, III, 248), "No menos habilidad tenían, según don Gregorio de Tapia y Salcedo...» (Larra, Obras, I, 27), "La traducción (...) según él, tenía un carácter frívolo»(M. Pelayo, Cartas a Juan Valera, 263).

Es en este tipo de construcciones donde aparecen los más de los casos que se citan de según con formas pronominales de nominativo; sin embargo, hay que hacer constar que se documentan escasamente, y no he logrado encontrar ejemplos anteriores al siglo xIx (es posible que existan, por supuesto, pero bastante aislados):

"Según tú, yo estoy en pecado mortal porque visto bien» (Galdós, León Roch, I, 152, apud Meyer-Lübke, Grammaire des Langues Romanes III, Reprint 1923, § 209), «El público es, según yo, muy respetable, y según Lope y Alarcón, muy necio y muy bestia» (A. de Trueba, Cuentos, 123), «Es decir, que, según tú, el que tiene dinero no tiene ninguna obligación» (Zunzunegui, Estos hijos, 127), «Y en la música española ha influido mucho Andalucía. - Según "Cantares", decisivamente, ¿no?.-Según yo, si” (Cambio 16, 17-XII-1978, 87).

No es difícil oír ejemplos en el habla, parece que con una cierta mayor frecuencia, sobre todo con $t u$, ya que con yo supone una redundancia que sólo se permite en contextos muy marcados.

15 Cfr. Alexander Souter, A Glossary of Late Latin, Oxford, 1949, s. v. secundum. 
En todos los casos de este empleo de según, pero especialmente cuando se implican las dos personas del diálogo, la construcción presenta un claro valor de contraposición de opiniones o puntos de vista, o un deseo de marcar claramente la responsabilidad de lo enunciado en la frase: es decir, un uso propio del discurso dialéctico, e incluso polémico. Por otro lado, al indicar simplemente la fuente originaria de una opinión, enunciado, etc., ha pasado a ser una forma general del lenguaje periodístico.

Por otro lado, esta construcción con según suele aparecer separada del cuerpo del enunciado por medio de una pausa (traducida en la grafía por una coma), y con tonema de anticadencia cuando se coloca en primer término. También puede aparecer en el interior de la oración, pero aislada igualmente entre pausas. Es decir, constituye un elemento periférico, que puntualiza el sentido en que ha de interpretarse el enunciado; sintácticamente, no es un complemento del sintagma verbal, o del verbo, sino de toda la oración, pues se refiere a toda ella. En esto se diferencia de otras construcciones con según que pueden referirse al verbo, como complementos modales: "se ha hecho según la costumbre» ( $=$ "...del modo que manda la costumbre»); y se asemeja a otras que pueden aparecer como englobadoras de toda la oración, y sin sentido modal: "se ha hecho, según la costumbre» (es decir: "la costumbre manda que se haga algo, y se ha hecho") ${ }^{16}$.

Los ejemplos que hemos presentado del tipo según yo, etc. desmienten la afirmación de M.a Luisa Rivero ${ }^{17}$ en el sentido de que frases como "según yo, nos podemos ir ya» son agramaticales, mientras que no lo sería "Juan dice que, según yo, nos podemos ir ya». Con esto trata de defender la antigua tesis de Bello, resucitada por los filósofos del lenguaje y adoptada por algunos generativistas, de que toda frase asertiva es, en la estructura profunda, complemento de un verbo de "decir". Con según no es posible que el nombre que introduce sea idéntico al del verbo de "decir» dominante: de ahí el distinto comportamiento de ambas frases. Sin embargo, aunque compartimos esta interpretación de las frases asertivas (ya que toda frase asertiva es un acto

16 La misma variación semántica se da cuando introduce oraciones: «se hizo según dijiste» / «se hizo, según dijiste»; ocurre también con como: «se asustó como su hermana" / "se asustó, como su hermana», «no vinieron como pensaban» / «no vinieron, como pensaban»: esta última con dos interpretaciones, según el ámbito de la negación: "no pensaban venir y no vinieron" / "pensaban venir, pero no vinieron".

17 «La concepción de los modos en la gramática de Andrés Bello y los verbos abstractos en la gramática generativa", en Estudios de gramática generativa del español, Madrid, Ed. Cátedra, 1977, pág. 81. 
de decir), el argumento de según nos parece contradicho por los hechos, ya que los casos de según yo que hemos encontrado, p. ej., son del tipo que Rivero decreta como agramatical. Por otro lado, nos parece una restricción muy limitada (o ad hoc): ¿por qué no sería agramatical del mismo modo «según pienso yo, nos podemos ir ya»? Es cierto que las frases consideradas agramaticales por Rivero no se enuncian normalmente, y menos como «ejemplos» sin ningún tipo de contexto, y no son frecuentes. Pero la razón no es sintáctica, sino semántica, o mejor aún lógica: son redundantes, y no aportan nada nuevo, ya que un enunciado como «nos podemos ir ya» se interpreta automáticamente como manifestación de la opinión o parecer del hablante; añadir «según yo» no tiene, pues, ningún sentido. Por ello, se encuentran en contextos de énfasis o contraposición de lo enunciado por el hablante con lo que ha dicho otro: éste es el tipo de actos de discurso en que hemos encontrado tales construcciones, lo cual está plenamente justificado si atendemos a su significado.

Se ha planteado en ocasiones el problema de si según, no sólo en estos tipos sino en todos sus usos, puede considerarse preposición ${ }^{18}$. Históricamente, no hay ninguna duda: todos los empleos de según arrancan de antiguas preposiciones, latinas o griegas; al mismo tiempo, parten del valor semántico básico de 'conformidad' o 'adecuación' que ya tenía en latín como preposición. A partir de ahí, pasó a poder introducir oraciones, incluso sin el nominalizador que, con los mismos valores que ante sustantivo; por ello, en muchas ocasiones podemos considerar un verbo latente: más que eso, lo que ocurre es una analogía de valores significativos entre los dos esquemas sintácticos posibles en según.

Ahora bien, puede arguiirse que si lo anterior es cierto desde una perspectiva diacrónica, no tiene por qué serlo sincrónicamente: los empleos de según con sustantivo podrían ser resultado de elisión de verbos, por ser su sentido fácilmente recuperable, por lo que según sería en todos los casos un adverbio relativo de modo, o una conjunción subordinante. Este análisis es posible, aunque entonces la alternancia según-según que para introducir oraciones, existentes ambas desde los comienzos del idioma, aunque menos frecuente la segunda, no parece plenamente justificada. Más complicada es la tesis de la antigua Gramática de la $\operatorname{RAE}(\S 416)$ : a partir de frases como "según lo que dices» (muy frecuentes siempre) es posible un doble proceso de elisión: uno

18 Alarcos, en Gramática estructural (reimpr.), Madrid, Ed. Gredos, 1969, página 83, la excluye del inventario de preposiciones, ya que acaso sólo rige morfemas 'extensos' o verbales. 
elimina el relativo y su antecedente neutro («según dices»), y otro sólo el antecedente («según que dices»); en principio, tampoco hay nada reprochable: pero como la RAE pensaba también que frases como «según él» surgían por elipsis de «según dice él», nos encontramos con un largo proceso de elisiones, que empieza en un empleo preposicional, sigue con un valor de adverbio relativo, y termina con otro uso semejante al de preposición. Creemos que son demasiadas elipsis para explicar estas construcciones ${ }^{19}$.

Más simple parece suponer que según funciona, en todos los casos en que precede a sustantivo, como preposición (lo que viene confirmado por la historia). Como otras preposiciones, introduciría oraciones por medio de que anunciativo; pero su valor modal lo asimilo muy pronto al adverbio relativo como ${ }^{20}$, adquiriendo algunas de sus posibilidades sintácticas, como introducir directamente oraciones (o elementos predicativos, frecuente en castellano medieval). La existencia de sintagmas del tipo como yo, como tú, etc., por un lado (aunque de valor no idéntico al de según yo, etc.; en cambio «según dice Juan...» = «como dice Juan...»), y por otro la de frases como "según digo yo», «según dices tú», existentes desde el siglo xIII, provocó la interferencia de construcciones, originándose según yo, etc., formas que por otra parte se documentan tarde en castellano, y sólo en contextos muy marcados. En el fondo, según yo o según tú son herencia de empleos latinos inequívocamente preposicionales, donde secundum regía acusativo, contaminados con otras construcciones sintácticas de valor semántico muy próximo.

3. El empleo de entre con sintagmas nominales en función de sujeto se da ya en los primeros textos castellanos, p. ej. en el Poema del Cid, con una frecuencia y una gama de valores relativamente estabilizados que hacen pensar en la antigüedad de la construcción. Sin embargo, en latín inter no se daba en tales contextos, a pesar de lo cual se encuentra, aparte del español, en francés y provenzal antiguos y en italiano. Más que en un desarrollo paralelo, pero independiente, de las diferentes lenguas románicas, hay que pensar en la continuidad de un uso propio del latín vulgar y tardío.

Su origen ha de estar, como señala Lapesa ${ }^{21}$, en el empleo de «inter nos», «inter ipsos», como complemento en frases recíprocas. También

19 Ya BeLLo, Gramática, § 71, nota, hacía ver el peligro de jugar demasiado con la noción de 'elipsis'.

20 MEYER-LUtBKE, Grammaire, III, §§ 209 y 568, insistió en este punto, con paralelos en otras lenguas románicas.

21 «Los casos latinos: restos sintácticos y sustitutos en español», en BRAE, t. XLIV, 1964, págs. 57-105, espec. pág. 60. 
Cuervo $^{22}$ apuntó hacia los casos en que sintagmas como «entre sí se refieren al sujeto de una frase recíproca. Así, de frases como «los cristianos se mataban entre ellos", puede pasarse, omitiendo el sujeto, a "se mataban entre ellos», o, con inversión del orden, «entre ellos se mataban». Aquí, el pronombre introducido por entre se identifica con el sujeto de la frase. O se puede partir de frases pasivas donde el sintagma con entre indica a la vez el agente nocional y el término de la acción, con sentido recíproco:

«Escrito es de suso como entre el Papa Benedito y el rey de Aragón era acordado de..." (Crón. Juan II, 9.7, apud Cuervo, Dicc.), "Entre los dos se consultó mi muerte» (Lope, Dorotea, 21, apud C. Fdez., Vocabul. Lope).

Este tipo de construcciones recíprocas puede explicar fácilmente la presencia de entre con sujetos.

Desde el Poema del Cid, encontramos la construcción con sentido recíproco, denotando su origen:

"Entre Minaya e los buenos que í ha / acordados foron quando vino la man" (Cid, 3058), "cuando fablamos entre mí et vos sobre estas razones...* (DJManuel, Libro Estados, 1.83, apud Cuervo), "entre los tres pasaron un graciosísimo coloquio" (Quijote, 2.2, ibid.), etc.

Pero en otros casos ha perdido ya ese valor recíproco, e indica sólo la actuación conjunta de los individuos referidos por el sujeto:

«Entre los de Teca e los de Terrer la casa / e los de Calatayut (...) así lo an asmado e metudo en carta» (Cid, 842-844), eentre io et mi carillo, / ganamos buena soldada» (Canc. Stúñiga, apud Cuervo, n. 123), "mejor daríamos entre él y mí orden en la manera... (H. Cortés, Cartas y relaciones, apud Keniston 23, 63), "con unas tijeras iban cortando pelo a pelo entre dos criados» (M. Alemán, Guzmán, ibid.), "Entre seys dellos traían unas andas (Quijote, 1.13), "Entre los dos me dexaron casi en el vltimo aliento" (Lope, Cordobés valeroso, 99, apud C. Fdez., Vocabul. Lope), «a este tiempo le levantaron entre Figueroa y don Juan de Jáuregui» (Moratín, Derrota pedantes, apud Cuervo, Dicc.), «...después de que entre los dos los habíamos roto» (Galdós, Lo prohibido, 211), "...que entre todos habían de salvarnos" (Benavente, Intereses creados, 2.3.9, apud Cuervo, Dicc.).

En castellano medieval, entre indicaba también la simple coincidencia en la realización de una acción, valor hoy perdido:

22 Diccionario de construcción y régimen de la lengua castellana, Bogotá, Instituto Caro y Cuervo, 1953, s. v. entre.

${ }^{23}$ The Syntax of Castilian Prose. The Sixteenth Century, The University of Chicago Press, 1937.

LXII, 3.0-4. -3 
"Entre él e Albar Fáñez hivan a una compaña» (Cid. 1549), "Más se maravillan entre Diago e Ferrando» (íd., 2348), «en senos cavallos cavalgan entre el rey e el castellano" (Rodrigo, 1034, apud M. Pidal, Cantar, I, 390).

Lo mismo ocurría con sintagmas nominales en otras funciones: "Entre yo e mio Cid pésanos de coraçón» (Cid, 1959). Hay que distinguir estos casos de otros, muy semejantes en la forma, donde el sintagma con entre concurre con el sujeto de la frase, o con el objeto directo, especificando el número o conjunto integrado por ese sustantivo:

"Entre Rachel e Vidas aparte yxieron amos» (Cid, 192), «Entre oro e plata fallaron tres mill marcos» (íd., 1737), «El que ouiere ciento entre oueias e cabras..." (Fuero Madrid, apud Cuervo, Dicc.), "Et murieron aquel día de los de Ay, entre uarones e mugieres (...) doze uezes mill» (General Estoria, 2." parte, 1), "eran seis mill hombres entre arcabuceros y ballesteros" (DHurtado de Mendoza, Guerra, Lib. 3), "los castellanos no eran más que 1700 hombres de armas y 400 peones entre ballesteros y lanceros" (Quintana, D. Alvaro de Luna, apud Cuervo, Dicc.).

Como vemos, el sintagma con entre, aunque puede estar separado, se refiere, especificándolo, a un sustantivo; por lo tanto, aunque semánticamente puedan estar próximos a los casos anteriores, sintácticamente han de analizarse estos sintagmas como complementos determinantes de un sustantivo: la preposición conserva su valor funcional de elemento subordinante.

El empleo de las formas de nominativo de los pronombres con entre conoció en el castellano una larga serie de vacilaciones: parece que como consecuencia del empleo de yo, tú cuando entre acompañaba al sujeto se ha extendido también a los casos en que introduce complementos: "entre tú y yo lo haremos», "la cosa está entre tú y yo». Una relación exhaustiva de los distintos empleos es la que proporciona Cuervo en la nota 123 a la Gramática de Bello.

No hay acuerdo en los gramáticos a la hora de definir el status funcional de entre en estas construcciones. Su valor semántico está muy claro, y es el que posee como preposición en los demás contextos: señala los límites explícitos entre los cuales ocurre, se da o se hace algo; inclusión de algo en una extensión delimitada entre puntos precisos. Por ello, entre, en todas sus funciones, introduce siempre un sustantivo plural semánticamente: "está entre los árboles», "se perdió entre la multitud», o un sintagma nominal coordinado: "entre la carretera y la casa hay algunos árboles». Sin embargo, cuando acompaña a un sintagma nominal que funciona como sujeto, no puede conside- 
rarse preposición, ya que no indica su subordinación respecto de otro elemento de la frase: el sujeto no es elemento regido, y aun si lo consideráramos así (como hace Tesnière) su subordinación respecto al verbo no viene marcada en español, ni en otras lenguas, por una palabra morfemática como la preposición; ésta aportará un valor semántico nuevo, pero en ningún momento será índice funcional del sujeto (en cambio, el predicado nominal exige a veces preposición, no sólo para aportar un sentido específico, sino para poder funcionar como tal: esto no ocurre con entre + sujeto).

Algunos lingüistas, sin embargo, siguen hablando en estos casos de uso de preposición con sujeto. Por ejemplo Hanssen ${ }^{24}$, aunque sin justificarlo, o M. ${ }^{a}$ Luisa López ${ }^{25}$, en lo cual sigue a Pottier ${ }^{26}$ : para estos dos últimos nos encontramos aquí con el valor 'nocional' de entre; ahora bien, a pesar de que consideran a algunos adverbios, preposiciones y conjunciones de subordinación dentro de la misma clase funcional, sin embargo afirman que todos estos elementos ponen en relación dos términos (uno de los cuales puede faltar: caso de los adverbios), y en relación de subordinación: precisamente esto es lo que falta aquí, ya que no hay nada que pueda regir el sintagma con entre; ni uno ni otro aluden a tal contradicción.

Otros linguiistas hablan de entre... y... como locución conjuntiva. Ya señaló esto Meyer-Lübke al incluir estos usos de entre en el esquema de la coordinación copulativa ${ }^{27}$; este fenómeno no es exclusivo de entre sino que se da con otras preposiciones: "pater et mater veniunt» "pater cum matre veniunt" / "pater cum matre venit». Este hecho, a propósito de con, es también conocido en español: «El padre con las fijas loran de coraçón» (Cid, 2632) ${ }^{28}$. Esta tesis fue aceptada por Menéndez Pidal ${ }^{29}$, la antigua Gramática de la RAE ${ }^{30}$, Gili Gaya ${ }^{31}$ y el Esbozo ${ }^{32}$. La razón para analizarla como coordinante copulativa es que los ele-

24 Gramática histórica de la lengua castellana, París, 1966, § 497.

25 Problemas, pág. 137.

26 Gramática del español (versión española de A. Quilis), 2.a ed., Madrid, Editorial Alcalá, 1971, pág. 69.

27 Grammaire, III, §§ 217, 218.

28 La asimilación a conjunción coordinante se produce también con adverbios o locuciones adverbiales: tanto como, asi como, bien... bien, ya... ya, etc.; cfr. BeLLo, Gramática, § 838.

29 Cantar de Mio Cid. Texto, gramática y vocabulario, 4.a ed., Madrid, EspasaCalpe, 1964, I, §§ 129.1 y 190.11 .

30 Gramática de la lengua española, Madrid, Espasa-Calpe, 1931, §§ $265 j, 319$ a.

31 Curso superior de Sintaxis española, 9. ${ }^{a}$ ed., Barcelona, Biblograf, 1967, §§ 156 y 200 .

32 Esbozo de una nueva gramática de la lengua española, Madrid, Espasa-Calpe, $1975, \S 3.17 .3 c$. 
mentos que une son de igual valor funcional, especialmente sujetos, y que sólo desarrolla un sentido de cooperación implícito en la copulación simple: "tú y yo lo haremos» $\rightarrow$ "entre tú y yo lo haremos». Gili Gaya justifica además el análisis observando que los pronombres van en caso sujeto, sin actuar el régimen propio de la preposición; las vacilaciones antiguas se deben al paso del valor de preposición al de conjunción.

Sin embargo, es más problemático hablar de conjunción copulativa en frases como "entre nosotros lo haremos», aunque suele extenderse también esa definición a estos casos. Podría arguiirse que todo sintagma nominal en plural es resultado de la coordinación de una serie de elementos individuales que constituyen un conjunto. Esto vendría apoyado por el hecho de que en el tipo de construcciones que estamos examinando no pueden aparecer sustantivos colectivos (plurales por significado, pero no en forma): * «entre la multitud lo hizo-hicieron* / «se perdió entre la multitud». De este modo, si consideramos que nosotros = yo $+t \dot{u}+\ldots$, el análisis como locución conjuntiva podría ser válido.

Sin embargo, no parece aceptable un análisis semejante. Es cierto que en el tipo medieval donde entre... $y \ldots$ significaba sólo coincidencia en la acción (no tengo ejemplos de entre con sintagma plural en tal valor), la identidad semántica con la simple coordinación parece casi total, y podría equivaler a una locución conjuntiva. Pero la presencia de entre con los otros valores aporta un contenido semántico muy preciso, que no es propio de una conjunción, cuyo valor se limita a enlazar oraciones o elementos de oraciones $(y)$, presentarlos como alternativas (o), o bien oponerlos (pero). Por otro lado, el desarrollo en elementos individuales coordinados de los sintagmas plurales plantea problemas, sobre todo si se presenta como una transformación sintáctica ${ }^{33}$ : "todos los hombres» sería la coordinación de infinitos elementos (¿y cuál sería su relación con "todo hombre»?), o de un número impreciso en "muchos-algunos... hombres», 0 , si se desconoce el referente, en «las sillas del cuarto son blancas»; además, una frase como "hay sillas» no puede surgir de * «hay silla + silla...». En el texto como tal, entre en "entre todos lo haremos», etc., no coordina nada, pues la coordinación sintáctica enlaza elementos dados, no implícitos.

Pero sobre todo, ni siquiera «entre tú y yo lo haremos» puede considerarse locución conjuntiva, parangonable a «tanto tú como yo lo haremos", u otras: entre se aplica a los dos elementos, mientras que

33 Cfr. Ana M.a BarRenechea, "A propósito de la elipsis en la coordinación», Studia Hispanica in Honorem R. Lapesa, II, Madrid, Ed. Gredos, 1974, págs. 105-121. 
en las otras cada miembro de la locución se aplica a uno solo, el que va junto a él, y es por lo que se consideran elementos conectivos. Gráficamente, podríamos representar la diferencia del siguiente modo:
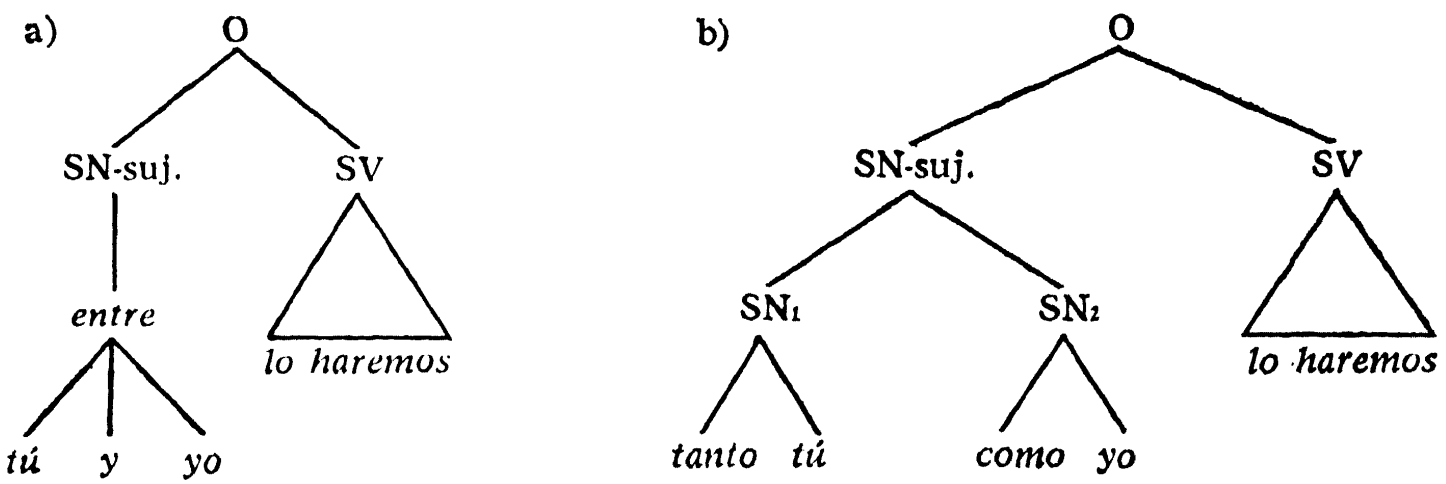

La idea de cooperación en la acción, o reciprocidad, la aporta entre sobre la relación existente entre todos los elementos que componen el sujeto, sean varios en coordinación sintáctica o subsumidos bajo un sustantivo en plural, y la acción o proceso indicado por el verbo; las otras locuciones conjuntivas sólo señalan, con mayor o menor énfasis, que cada elemento realizó la acción: es decir, presentan un puro valor aditivo; además, pueden enlazar, como toda conjunción o elemento equivalente, sintagmas en cualquier función (con preposición o sin ella) y oraciones: nada de esto es posible con entre... y...

Creemos, pues, que en estos casos entre ha de considerarse funcionalmente adverbio. Esta opinión la sustentaron ya, entre otros, Keniston ${ }^{34}, \mathrm{M}$. Seco ${ }^{35}$ y Hernández Alonso ${ }^{36}$. Presenta un sentido de aen cooperación", y con un ámbito de aplicación referido a la relación sintáctica y semántica Sujeto-Verbo: no sólo se dice 'quiénes' realizaron la acción, sino también 'cómo' la realizaron; podría incluirse, pues, entre los adverbios modales en estos contextos; su modificación se realiza, no sobre el verbo solo, o incluso el SN sujeto solo, sino sobre la relación entre ambos. En este sentido, puede alternar con verdaderos adverbios como conjuntamente, mutuamente, o con sintagmas de valor adverbial como en unión, en cooperación, etc. No obstante, entre mantiene de su origen preposicional el hecho de que ha de aparecer siempre junto al sintagma nominal, sin posibilidad de separarse de la oración, enmarcándola a través de pausa, como otros adverbios. Por otro lado, tampoco puede ser convertido en el «foco» de la oración, es

34 The Syntax, pág. 6.

35 Gramática esencial del español, Madrid, Ed. Aguilar, 1972, pág. 178, n. 1.

36 «El adverbio», Thesavrvs, t. XXIX, núm. 1, 1974, págs. 48-67, espec. pág. 64. 
decir, el elemento marcado como «información nueva»: «conjuntamente es como lo hicieron Juan y Pedro» / * «entre es...».

Debido al significado especial que aporta, entre presenta restricciones peculiares sobre la relación Sujeto-Verbo que modifica: la acción verbal ha de concebirse como única, aunque realizada por varios; parece que esa unicidad, desde el punto de vista linguístico, viene dada por la relación entre la acción o proceso verbal y el complemento de objeto directo: por lo menos, esto es lo que explicaría su casi exclusiva presencia en oraciones transitivas: «entre los dos lo mataron", «entre Juan y Pedro poseen la mayor parte del pueblo». Es cierto que en "entre los dos mataron a sus enemigos» se hace referencia a una serie de acciones individualizables, pero concebidas como totalidad. En cambio, no existen, por lo menos desde la época clásica o antes, frases del tipo * «entre él y Juan vinieron»; y son de muy dudosa aceptabilidad (no las he podido documentar) otras como ?«entre él y Juan trabajan mucho». En esto, las locuciones con entre se diferencian de las locuciones conjuntivas señaladas: "tanto él como Juan vinieron», pero también de otros adverbios de modo que pueden calificar simplemente la acción verbal: «él y Juan trabajan conjuntamente mucho».

Intimamente relacionada con la aparición de entre ante sujetos, ha de considerarse su presencia con adjetivos referidos a un sustantivo, bien en incidencia directa, bien a través de un verbo atributivo o similar. Citamos ejemplos del Diccionario de Cuervo:

«Paresce más prieto que amariello, et las espaldas entre amariellas et pardas» (DJManuel, Libro Caza, 3), «Entre tristes y alegres (...) siguieron su camino» (Persiles, 1.11), "Un lacayo / medio francés, entre bermejo y bayo» (Lope, Obras sueltas), a...una florecita así llamada en la lengua aimara, de color entre blanco y morado» (Cobo, Historia Nuevo Mundo, 1.4.54), "quedó por un rato entre confuso y pesaroso» (Solís, Conquista Méjico, 5.15), etc.

Evidentemente, parte del valor preposicional, e incluso podría rastrearse un valor locativo que explicita límites: son posibles paráfrasis como "un color situado entre blanco y morado" $u$ otras semejantes. Por otra parte, entre podría considerarse en el grupo de preposiciones que introducen adjetivos predicativos, o adjetivos como complemento de un pronombre («acusarlo de cruel», «algo de bueno»); sin embargo, un adjetivo prepositivo calificando directamente a un sustantivo es construcción inusitada en español ${ }^{37}$. El valor de entre en este tipo de

37 El tipo «una torre de veinte metros de alto» (- *...a*) es cruce entre *una torre veinte metros más alta» y auna torre de veinte metros de altura». 
frases es también adverbial: viene exigido por razones semánticas sólo, pero no para marcar funcionalmente al elemento que introduce como predicado; aporta una caracterización modal, a partir de la cual puede alternar con adverbios como aproximadamente, o expresiones como a medias, más o menos, etc. (por supuesto, no con el mismo significado: por eso se opone a ellas). Aquí también entre se aplica sobre los dos elementos coordinados, y no se limita a coordinar uno con otro. Además, en estos casos exige elementos coordinados solamente, y no sintagmas en plural.

Por tanto, la extensión de entre a función adverbial se establece, de forma clara, en dos casos: cuando modifica la relación Sujeto-Verbo desde el punto de vista del sujeto, o cuando modifica a adjetivos coordinados. Su carácter de preposición se mantiene en su atonicidad, por un lado, y su inmediatez respecto a los elementos que modifica.

Una situación límite, respecto al primer caso, la representan frases como: "Entre Rachel e Vidas aparte yxieron amos» (Cid, 192), donde el sintagma con entre aparece con una serie de sustantivos coordinados que podrían considerarse aposición al sujeto. $Y$ respecto al segundo caso, frases como:

"con un género de impaciencia, entre cólera y turbación" (Solís, Conquista Méjico, 2.5), "se oyó un ruido entre carraspeo y tos» (Carrasquilla, Frutos, 1).

Sin embargo, aquí podemos hablar del esquema, normal en castellano, de un sintagma preposicional que funciona como complemento de otro sustantivo: la preposición sigue cumpliendo su papel de elemento transpositor.

4. Hay otro tipo de casos en que entre aparece con sintagmas en función de sujeto: "han venido entre treinta y cuarenta personas». Sin embargo, la situación es diferente, ya que la preposición puede hallarse también ante sustantivo en función de objeto directo: «Lope escribió entre mil ochocientas y dos mil piezas dramáticas» (Moratín, Obra póstuma, apud Cuervo, Dicc.), o de complemento temporal: «llovió entre cinco y diez días»; en cambio, con sustantivos como término de otra preposición su presencia es prácticamente imposible: * «se lo he dado a entre veinte y treinta personas", "vino con entre veinte y treinta personas" (sin embargo, entre puede combinarse detrás de por, de, hasta).

Por otro lado, en este tipo de uso coincide con otras preposiciones, siempre que el sustantivo al que acompañan vaya modificado por un 
numeral, o éste funcione como término primario: «vinieron entre treinta y cuarenta (como término primario en la estructura superficial, aunque siempre parece sobreentenderse un sustantivo elidido). Las preposiciones que pueden aparecer, además de entre, en tales contextos son hasta, sobre, y algunas otras.

Hasta indica límite en la estimación numérica, a partir de su valor primario de 'movimiento' (tanto en el plano espacial como temporal), aludiendo al término absoluto del movimiento; así, con numerales indica «no más de tal número». Se encuentra ya en castellano medieval:

«E juntaronse alli aquell dia fasta çien cavalleros, o mas...» (Gutierre Diaz de Games, Victorial, c. LXXXII), "y caminaron para ella con hasta seis mil hombres mal armados» (DHurtado de Mendoza, Guerra, Lib. I), *y echando el esquife o barca al mar entraron en él hasta doze Franceses» (Quijote, 1.41), «...hornilla que suele tragarse hasta medio carro de paja» (Jovellanos, Obras, III, 168), "había en la sala hasta un par de docenas de personas» (Baroja, Los últimos románticos, apud M. Seco, Dicc. ${ }^{38}$, s. v.).

En algún caso aparece junto a un sustantivo sin numeral por traslado de su lugar originario en el sintagma complemento de ese sustantivo: "un muchacho de hasta edad de once años» (Cervantes, Licenciado Vidriera). Como hemos visto, a diferencia de entre, puede aparecer hasta en un sintagma ya introducido por otra preposición, aunque no sea construcción frecuente.

El mismo uso puede tener sobre: "han asistido sobre quinientas personas»; el Diccionario de Autoridades recoge este uso, afirmando que indica el exceso corto de alguna cosa en número: "tendré sobre cien reales» significaría "...poco más de...»; sin embargo, indica más bien cantidad aproximada, por arriba o por abajo de la expresada (como indica el DRAE, en la edición de 1970). También se encuentra en este empleo la secuencia de... $a$, que indica cantidad intermedia entre la introducida por de y la por $a$ : «han venido de veinte a treinta personas».

En este tipo de construcciones las preposiciones españoles continúan un empleo semejante de sus antecesoras latinas: ad y supra podían ir con nominativo indicando límite cuantitativo:

«ad mille trecenti Carthaginiensium caesi sunt» (T. Livio, 23, 37, 6), «supra duo milia septigenti» (id., 30, 6, 9) ${ }^{39}$;

\footnotetext{
38 Diccionario de dudas de la lengua española, 4.a ed., Madrid, Ed. Aguilar, 1966.

39 Cfr. O. RIEMAN, Syntaxe, § 129.
} 
en estos empleos continuaban sus primitivos valores adverbiales, y de ahí que no establecieran la rección normal de caso. Ese mismo carácter funcional de adverbio es el que hay que dar a estas preposiciones españolas en tales contextos: no indican rección sintáctica de un término por otro, por lo que no funcionan como preposiciones; en segundo lugar, no se refieren a todo el SN, sino sólo al numeral, es decir, a un elemento que modifica al sustantivo: desempeñan, pues, función terciaria, típica del adverbio; y pueden alternar en tales contextos con adverbios como aproximadamente, escasamente, casi, etc. que implican valor cuantitativo. Otros adverbios exigen de para introducir al sustantivo modificado por un numeral: "más de veinte personas", "menos de diez días», "cerca de catorce años». Algunos gramáticos ${ }^{40}$ consideran a más y menos en estas frases como términos primarios, y el sintagma con de su complemento (sobre la base del esquema comparativo). Sin embargo, cuando funcionan como sujeto, la concordancia se establece siempre sobre el sustantivo: "han venido más de mil hombres"; y cuando son objeto directo se realiza la pronominalización sobre el sustantivo: "han venido más de mil hombres, pero no los he visto" (claro que esto podría ser un tipo de concordancia 'ad sensum'). Pero nos inclinamos a considerarlos elementos adverbiales, que exigen de (o que en frases negativas) por su origen en las estructuras comparativas, no sólo por su analogía semántica con otros adverbios inequívocamente tales en contextos semejantes, sino por su paralelismo sintáctico con cerca de, ya que cerca en ningún caso funciona como elemento primario.

5. Con un valor diferente al de 'límite cuantitativo' señalado en el párrafo anterior, podemos encontrar la preposición hasta delante de sintagmas nominales en función de sujeto; en realidad, con el mismo sentido aparece delante de sintagmas nominales en cualquier función, e incluso delante de verbos. Menéndez Pidal ${ }^{41}$ afirma que fasta tenía antiguamente uso adverbial precediendo a otras preposiciones, es decir, cuando encabezaba un sintagma nominal ya introducido por preposición. Sin embargo, no creemos aceptable tal opinión. Los casos a que alude Pidal, y otros del mismo tipo, son:

"senior a a seer da oriente / de todos hata in occidente" (Auto Reyes Magos, 25-26), "Fata en Valençia sirvíalos sin falla" (Cid, 1556), "e mantouiesen castidat fasta en su muerte" (Crón. Veinte Reyes, IV), "bien me-

40 Bello y Cuervo, Gramática, §§ 1016-1018, notas 126 y 127; S. Fernández Ramfrez, Gramática española. Los sonidos, el nombre y el pronombre, Madrid, 1951, § 81. 41 Cantar, I, \& 178.2. 
resçe de ser juez / de la mar fasta en Fez» (Villasandino, Cantiga, $15 \mathrm{f}-\mathrm{h}$ ), «...lo troxiese solo fasta en el tenplo del timbreo Apolo" (DAlvaro de Luna, Libro... mugeres, c. LXIII).

Todos los casos que cita Pidal, y los que hemos podido recoger, son de la combinación hasta + en. En todos ellos, el valor de hasta es el que tiene como preposición neta, acumulado al de en: uno de los numerosos casos en que un sintagma en español puede ir introducido por dos preposiciones, sin que ninguna de ellas pierda su valor funcional propio: las dos son índice de la función complemento locativo, en este caso, sumando los sentidos de 'límite de movimiento' y 'dentro de'.

Los casos en que no funciona como preposición se dan en sintagmas de todo tipo, según ya hemos señalado: en ellos se parte del rasgo 'límite' propio de hasta en su función preposicional, aunque ya sin idea de 'movimiento' (espacial o temporal). Con ella se realza enfáticamente la veracidad del sintagma al que acompaña, $o$, mejor dicho, la veracidad de lo que éste realiza o le ocurre: es decir, aparece en el «límite» de lo que se puede creer, decir u opinar. De ahí que sea muy frecuente como último término, o «límite», de una enumeración, precedida o no por la conjunción copulativa $y$ : gradación conceptual en el carácter sorprendente o notable de los elementos seriados, que culmina en el introducido por hasta. Es también posible la interferencia con el tipo de construcciones: «Todos, desde Juan hasta Pedro, lo creen».

La primera muestra que he podido documentar de tal uso aparece en el Libro de Buen Amor, en yuxtaposición con el sujeto de la frase: "Anssy que los rromanos, fasta la criatura, / non podien aver fuego, por su desaventura» (v. 263 a-b) ${ }^{42}$. A partir del español clásico se hace construcción cada vez más frecuente, hasta el español actual, en donde abunda en todos los tipos de lenguaje. Así, aparece ante sujetos:

"Los mas biuen de rapina, como grifos y aguilas y gauilanes. Fasta los grosseros milanos insultan dentro en nuestras moradas los domesticos pollos" (Celestina, Prólogo), «...de otra manera miro yo tus cosas, que hasta tus vezinas me parecen bien» (íd., VII), "Hasta el hambriento lobo (...) era agradable ante mis ojos" (Montemayor, Diana, 73.27, apud M. Debax, Lexique ${ }^{43}$ ), "...porque hasta esta negra, que se llama Guiomar, es doncella» (Cervantes, Celoso extremeño), "Vuestro vestido que se gasta, la casa que se cae, el muro que se envejece y hasta el sueño cada día os acuerda de la muerte" (Quevedo, Sueños, 131-132), "Tienen las cosas

42 Corominas considera "muy sospechosa» esta estrofa: cfr. la pág. 132 de su edición del $L B A$ en Gredos.

43 Mrchelle Debax, Lexique de la Diana de Jorge de Montemayor, Université de Toulouse, 1971. 
su vez, hasta fas eminenclas son al uso" (Gracián, Oráculo, 20), "Siempre han de estar a prueva el ingenio, la cordura y el valor, hasta la belleza" (íd., 264), "Los reinos, las ciudades, las familias, hasta los institutos religiosos, hacen (...) aprecio de esta prerrogativa” (Feijoo, Teatro critico, III, 210), "...para que hasta los ricos nuevos mirasen con afecto a los Mendozas» (Valera, Ilusiones, 85), "El Doctor, su escudero Respetilla, el mozo de los mulos y hasta el arriero (...) comieron patriarcalmente en la misma mesa" (íd., 120), "En tal ambiente, hasta los más sanos concluyen por acomodarse» (Galdós, Lo prohibido, 153), "Todo esto es tan de clavo pasado, que hasta las señoras (...) pueden entenderlo" (A. Marchado, Juan de Mairena, 100).

Se encuentra también, con el mismo aumento progresivo de frecuencia, ante sintagmas en función de predicado nominal, objeto directo o indirecto, o complemento circunstancial (con o sin preposición, y con cualquier tipo de preposición):

*...cómo el pecador a de dar estrecha cuenta fasta de toda ociosa palabra» (Corbacho, 113), «...e enpeña sus balandranes, su espada, sus armas, el jubón, las botas, fasta las mesquinynas» (íd., 129), "asta la çera me alle despues en los ojos» (Sta. Teresa, Vida, apud Keniston, 586), "...aquel Señor que sabe hasta los pensamientos" (Lope, Dorotea, apud C. Fdez., Vocab. Lope), "Y temen los principes hasta las señas de los mudos» (Quevedo, Política de Dios, II, vii), "hasta en los frutos del entendimiento ai esse punto de madurez» (Gracián, Oráculo, 39), "esta mudanza de modas es muy incómoda, hasta para el uso de las palabras» (Cadalso, Cartas marruecas, XXXV), "ya hasta a los ingleses mismos les echa la última bendición" (Larra, Obras, I, 406), "...bromas como la que dio al Obispo, y hasta más pesadas" (Valera, Ilusiones, 61), "Doña Ana fue educada hasta con refinamiento" (ibid., 91), "preferiría a su prima hasta a la gloria (...) ya que hasta por mala comprendía él que podría amarla» (ibid., 134), "conoce hasta los menores hechos que ocurren en la casa» (Azorín, Doña Inés, 191), "...tan sin ninguna experiencia hasta de los más ingenuos indicios" (Pérez de Ayala, Los trabajos de Urbano y Simona, 50), "podrán ser hasta buenos patriotas» (Machado, Juan de Mairena, 96).

Finalmente, hasta aparece unido directamente a verbos; sin embargo, este fenómeno no lo encuentro documentado hasta el siglo XIX: pudo existir con anterioridad, por supuesto, pero de forma no general, y se extendería cuando hasta perdiera su fijación respecto a sintagmas nominales, herencia de su valor preposicional. Así:

"ha hecho una mejora, y hasta ha contribuido al aumento de la población" (Larra, Obras, I, 138), "hasta ha habido persona que ha devuelto su ejemplar» (ibid., 429), "De todo lo demás nada sabía, nada quería saber; hasta negaba la posibilidad de que nada se supiese" (Valera, Ilusiones, 61) «... y hasta intentaríamos leerle alguna vez» (Machado, Juan de Mairena, 58), «y hasta llegó a insinuar la hipótesis...» (ibid., 63). 
Que en este contexto el uso de hasta debía de ser ya antiguo, se deduce de Bello ${ }^{44}$ quien no alude a su modernidad, aunque sí al hecho de que en su tiempo era mucho más frecuente que en la época clásica.

En el español del Siglo de Oro el valor de hasta solía reforzarse con la adición de aun, de sentido muy próximo: aun siempre precedía, como en todos los casos en que iba con un sintagma preposicional. La secuencia aun hasta aparece también ante cualquier tipo de sintagma, pero, según la época en que se produce, no lo he documentado ante verbos:

"Aun hasta en esto me ha corrido buen tiempo" (Celestina, VIII), "...que aun hasta Castilla estuvo dividida" (J. de Valdés, Diálogo Lengua, 60), «y esto aun hasta entre la gente vulgar» (ibid., 62), «aun hasta para en esto son malas estas contraescrituras» (M. Alemán, Guzmán, Lib. III, c. IV), "que aun hasta los vestidos de cautiuos nos quitaran...» (Quijote, 1.41), "Y aun hasta los mismos pastores y cabreros conocieron" (ibid., 1.13).

No vuelve a encontrarse con posterioridad, o, por lo menos, no debió de ser tan frecuente. El porqué de su desaparición es el reproche que le hace Cuervo (Diccionario..., bajo aun): «redundancia que hoy se miraría desaliñada». De todos modos, su unión es el mejor testimonio de la cuasi-identidad de sentido entre ambas partículas.

Como puede comprobarse, hasta precede siempre inmediatamente al elemento que pone de realce; sólo en época más reciente, y quizás coincidiendo con su mayor frecuencia en tal empleo y el desarrollo de su presencia ante verbos (atenuándose uno de los rasgos de su origen preposicional), se producen intercalaciones como: *...con asiduidad y talento inauditos, eso si, y hasta si se quiere con genio..." (Pérez de Ayala, Novelas..., 45); de todos modos, no es frecuente.

El problema quizás más importante, aparte del tipo de categoría que hay que asignar a hasta en estos casos, es el de su ámbito de aplicación. En principio, cuando acompaña a sintagma nominal, sea cual sea su función, se refiere a éste solamente, aun cuando se coloque al comienzo del enunciado: "hasta los niños tuvieron que pagar el pasaje», "hasta ratas comieron durante la guerra», "hasta para los presos hubo palabras de consuelo», etc. Lo realzado no es, pues, toda la frase, sino sólo el elemento sintáctico que acompaña hasta. Ahora bien, lo realzado no es exactamente lo referido por ese sintagma nominal, sino el hecho de que se encuentre en la situación definida por la función sintáctica que desempeña. Es decir, en "hasta los niños vinieron» lo que ponemos

4. Gramática, $\S \S$ 1246-1248. 
de relieve no es el hecho de que haya tales o cuales niños, a los que nos referimos con el SN correspondiente, sino el que esos niños «realizaran» la acción designada por el verbo. Lo realzado es, pues, más bien la función sintáctica Sujeto-Verbo desde la perspectiva del primero (o la función sintáctica que el sintagma con hasta cumpla con respecto a otro elemento).

Recientemente, Heles Contreras ${ }^{45}$ analizó hasta y otros elementos (algunos, de comportamiento sintáctico no idéntico) como 'rematizadores': marcan a toda la oración, o a un constituyente de ella, como 'rema', elemento que aporta 'información nueva' en el contexto de la enunciación, frente al 'tema' o 'información dada' (la ya presente en hablante y oyente al realizar el acto concreto de comunicación) ${ }^{46}$. De acuerdo con su perspectiva, que parece ser también la de Chafe, la asignación de 'rema' o 'tema' no se hace a los sintagmas nominales (o a otras partes de la oración) en cuanto elementos "referenciales", sino a su situación en la estructura semántica de la frase (agente, instrumento, beneficiario, etc.); no obstante, 'rema' o 'nuevo' pueden indicar también lo "referido" por ese elemento, aparte de su función sintáctico-semántica dentro del enunciado: en ocasiones, estos lingüistas no distinguen suficientemente la aplicación de tales conceptos. De ahí el problema de la pronominalización: en general, se considera que los pronombres sólo aportan 'información dada' (ya que aluden a algo aparecido ya en el contexto); sin embargo, Chafe ${ }^{47}$ encuentra que es posible pronominalizar un elemento 'nuevo' en oraciones contrastivas ("fue él quien lo hizo»), por lo que propone otra etiqueta: 'foco'. Por su parte, los pronombres (sólo los tónicos) pueden aparecer con hasta, aludiendo a alguien o algo inmediatamente presente en el contexto: "Pero ¿es posible que Juan hiciera eso? - Sí, por desgracia hasta él lo hizo". Como ya apuntamos, lo 'nuevo' no es la introducción de «Juan» en el discurso, sino su introducción como sujeto (o 'agente', desde una perspectiva semántica). En realidad, tampoco es 'nuevo' el concepto destacable (en cierto modo, ya está en el contexto que «lo

45 El orden de palabras en español, Madrid, Ed. Cátedra, 1978, espec. cap. 7 y págs. 131-135.

46 Para estos conceptos, surgidos en los lingüistas de Praga y recuperados posteriormente, pueden consultarse además: JOHN LyONS, Introducción en la lingüística teórica (versión española de R. CerDA), 2.a ed., Barcelona, Ed. Teide, 1973, pági. nas 348-356; M. A. K. HallidaY, "Estructura y función del lenguaje», en J. LyoNS, Nuevos horizontes de la lingüistica (versión española de ConXITA LlEó), Madrid, Alianza Universidad, 1975, págs. 145-173; Wallace L. ChaFE, Significado y estructura de la lengua (trad. de J. A. Domfnguez), Barcelona, Ed. Planeta, 1976, especialmente págs. 231-254.

47 Op. cit., pág. 283 , n. 2. 
hizo"), sino más bien 'realce', 'puesta en relieve', o alguna etiqueta semejante. Por tanto, el valor semántico de hasta no es el de señalar los elementos 'nuevos' de un enunciado, sino el 'énfasis' (como ya había visto la gramática tradicional) con que se presenta su función semántica en la frase. Ese 'énfasis' puede tomar diferentes matices, según el enunciado concreto en que aparezca: contraposición, límite de una enumeración, etc.

Hemos señalado más arriba que hasta enfatiza la relación sintáctica y semántica entre sujeto y verbo (en los casos en que acompaña al sujeto) desde la perspectiva del primero; en realidad, deberíamos decir que enfatiza la aplicabilidad del sintagma verbal o predicativo al sujeto, y no sólo del verbo. Por ejemplo, en «hasta los nuevos ricos miraban con afecto a los Mendozas» lo que se pone de realce es que sean también esas personas las que miraran de un modo determinado a otras, y no sólo que las miraran (por ello, en contextos semejantes se ha creído ver en hasta un elemento referido a toda la oración). Sin embargo, no podemos considerar a hasta como 'enfatizador' de todo lo que viene detrás; los complementos locativos o temporales, 'adjuntos' o 'circunstanciales' 48 , no participan de ello: "hasta los niños trabajaban con entusiasmo en aquel pueblo", donde lo único que se pone de realce es la aplicabilidad de la acción verbal, y su complemento de modo, al sujeto; en cambio, "hasta Juan trabajó en el andamio» es diferente, ya que ahí el locativo tiene un valor modal, especificador de un tipo de trabajo ("como albañil» o algo así). En suma: hasta, cuando aparece con sujetos (la situación es trasplantable a otras funciones), pone de relieve la relación de éste con el sintagma verbal ${ }^{49}$, enfatizando el hecho de que lo referido por ese sintagma nominal aparezca en tal función.

Por otro lado, hasta sólo se aplica a los elementos que van detrás: compárense: "hasta Juan trabajó en el andamio» - «Juan hasta trabajó en el andamio» - "Juan trabajó hasta en el andamio». El valor de último término, o 'límite', de una enumeración está presente, pero no como elisión de los términos anteriores, sino como 'presuposición' del enunciado ${ }^{50}$ : en la primera frase se presupone que otras personas trabajaron en el andamio, y lo que extraña es que Juan lo hiciera también; en la segunda, que Juan hizo otras cosas, sorprendiendo que

48 J. Lyons, Introducción, págs. 357-362.

49 Otra muestra, pues, de que esos complementos locativos o temporales no lo son del verbo sino de toda la oración.

50 De lo mucho escrito sobre este problema, lógico y lingüístico a la vez, una buena introducción puede ser: Tzvetan Todorov, L'énonciation, Paris, Larousse, 1970 ( = Langages, núm. 17). 
hiciera la de trabajar en tal lugar; y la tercera, que Juan trabajó de diversos modos y en diversos lugares, siendo lo enfatizado el modo que se expresa. Ahora bien, ante sintagmas nominales hasta sólo se aplica al inmediatamente posterior: de ahí que una frase como «tiraron hasta a los niños al agua» tenga la misma interpretación que "tiraron al agua hasta a los niños» (siendo lo enfatizado el 'paciente' de la acción expresada como tirar al agua). Sin embargo, $\mathbf{H}$. Contreras ${ }^{51}$ afirma que si en una frase como "María le escribió una carta hasta al presidente», donde al presidente es el único rema, colocamos hasta delante de una carta hay que interpretar ambos sintagmas como 'rema' (es decir, hasta se aplicaría a ambos). No lo creemos cierto ${ }^{52}$ : en "María escribió hasta una carta al presidente», al presidente sólo puede considerarse marcado por hasta si se analiza como complemento de una carta, pero no si se analiza como objeto indirecto de escribir. En el primer caso, estaría incluido dentro del sintagma del que es núcleo carta (sería un constituyente de nivel inferior), y por ello también quedaría enfatizado por hasta, ya que éste se aplica al constituyente sintáctico de la oración, de rango más elevado, y que le siga (en lo cual se incluyen el núcleo y sus modificadores); el análisis de al presidente como complemento preposicional (en función secundaria) de una carta es explicable si lo consideramos como paráfrasis (o derivado por transformación) de una carta dirigida al presidente (o simplemente como caso normal de complemento preposicional de un sustantivo).

La situación es algo diferente cuando hasta precede a un verbo. Como puede comprobarse en los ejemplos dados más arriba, la aplicación de hasta no se realiza sólo sobre el verbo, sino también sobre los elementos que le siguen, $y$ en concreto sobre todo el sintagma verbal o predicativo (excluyendo los 'adjuntos' locativos o temporales). Por otro lado, en estos casos, junto al valor de 'énfasis', parece tener mayor pertinencia el concepto de 'nuevo' o 'rema'. Por ejemplo, si lo referido con el sintagma los coches es consabido (es 'información dada', a lo que se debería la presencia del artículo determinado) una frase como "hasta quemaron los coches» puede entenderse con 'enfatización' exclusiva de la acción verbal; pero en "hasta quemaron coches" lo 'enfatizado es todo el sintagma verbal (ya que la ausencia de actualizador en el sustantivo indica su carácter de 'nuevo'). Naturalmente, la interpretación dependerá del contexto concreto de cada frase. Lo que, en cambio, no

51 Op. cit., pág. 134.

52 Aparte de que en "María le escribió hasta una carta al presidente», la presencia del le catafórico marca al presidente como 'tópico', es decir, 'no-rema': cfr. op. cit., cap. 9. 
parece aceptable es la afirmación de $\mathrm{H}$. Contreras ${ }^{53}$ de que hasta puede anteponerse a un predicado temático (es decir, no referirse a él): según él, por tanto, en "María hasta escribió una carta» son posibles dos interpretaciones, una con una carta y otra con escribió una carta como 'rema' (o elementos 'enfatizados'); de acuerdo con la primera interpretación, esa frase sería idéntica en significado a "María escribió hasta una carta». Creemos que la diferencia significativa es constante, según el orden que adopte hasta: en la primera oración, lo 'enfatizado' es el sintagma verbal, $\mathrm{y}$, por tanto, el verbo también; en la segunda, sólo el objeto directo. Pero en todos los casos hasta siempre ha de referirse al elemento que sigue, sea nombre o verbo.

Como es natural, la referencia exclusiva de hasta al verbo se da cuando éste es el elemento final de la frase: "los invitados hasta se emborracharon», "esos niños hasta cantan», "al coche hasta lo quemaron" (el elemento antepuesto pasa a ser el 'tema' o 'tópico' de la frase); parece que este hecho se da también cuando el complemento del verbo se reproduce junto a él como pronombre átono (alude a algo ya enunciado: es, pues, 'información dada').

Finalmente, señalaremos que no es usual que hasta aparezca en frases negativas, aunque el primer ejemplo que hemos documentado sea en una de este tipo. En estos casos se prefieren otros elementos como ni aun, ni siquiera, etc., que ya estudiaremos. Bello ${ }^{54}$, a propósito de la frase de Cervantes "y aun hasta a los encantados no perdona», afirma que le "sonaría» mejor: "y ni aun a los encantados perdona». Hay que tener en cuenta que la tendencia a no usar hasta se da sólo en frases formalmente negativas, no de significado negativo: * "hasta Juan no vino» / "hasta Juan dejó de venir».

5.1. En este tipo de empleo, hasta concurre, tanto en caracteres sintácticos como en valores significativos, con otras partículas castellanas. Como ya vimos, se acumulaba a aun en el español clásico: en efecto, aun aparece con valores semejantes en época antigua. Su significado primario es temporal: indica la continuidad de una acción o proceso, o de su no-realización, hasta el momento de la enunciación, o hasta el momento temporal señalado por el verbo. Es valor que siempre ha tenido: "Aun non so io morto" (Auto Reyes Magos, 109), "aún dormía cuando viniste», "para mañana aún no estará». Este sentido lo heredó del latino adhuc: pero éste sólo significaba "hasta ahora»

53 Op. cit., págs. 134-135.

54 Gramática, § 1248. 
(momento presente), mientras que "hasta entonces" (momento pasado, en el relato) se expresaba con etiam (el uso de adhuc con este último sentido no era clásico) ${ }^{55}$. Otro valor que ya presentaba adhuc era el 'inclusivo', especialmente en construcciones comparativas. Continúa en el español aún, ya desde los primeros textos, como gradación cuantitativa o cualitativa:

«que perderie los averes e más los ojos de la cara, / e aun demás los cuerpos e las almas» (Cid, 28), «...que todo esto, y avn mas a los hombres manifiestan" (Celestina, I), "como si éste no fuera tan nuestro como de los franceses, y aun un poquito más» (Larra, Obras, I, 17);

puede ir delante o detrás del elemento comparado, e incluso separado de él: «es aún más hermosa - «es más hermosa aún» - «aún es más hermosa»; el mismo valor es el que tiene cuando en la frase se presenta el pronombre otro:

"Aun otro miraclo vos querría contar» (Berceo, Milagros, 867 a), «Y avn otros hurtillos de mas qualidad alli se encubrian» (Celestina, I).

En todos estos casos, es el rasgo de 'continuidad' o 'persistencia', presente en su sentido temporal, el que se ha extendido a otros contextos. En latín, también etiam podía ir ante comparativos con el mismo valor. Así pues, la oposición adhuc/etiam se daba en el plano temporal, sobre la base de 'persistencia', como 'presente'/'no-presente' (aunque algunas veces adhuc se extendiera a lo 'no-presente'). Al poder usarse adhuc en lugar de etiam, en el valor temporal, acumuló también los sentidos gradativo e inclusivo que poseía etiam (como «también, hasta, incluso»), con ciertos matices adversativos, y que los gramáticos analizan como adverbio o conjunción (en el latín decadente etiam llegó a equivaler a et $)^{56}$ : con tal sentido, etiam podía aplicarse a un elemento de la oración o a toda ella. En la época postclásiça, adhuc pasó a poder utilizarse como aditivo (= "también») o inclusivo (= «hasta, incluso»), lo cual es de suponer que acarreó la desaparición de etiam en romance; ya en Séneca se encuentra adhuc... non (equivalente a ne... quidem $=$ no... incluso», "tampoco», "ni... siquiera»), donde el elemento oracional a que se aplica se encuentra entre ambos adverbios; en bajo latín llegó a significar también igual que et ${ }^{57}$. Su heredero castellano aun mantuvo y desarrolló estos valores.

55 O. Rieman, Syntaxe latine, § 148.

56 A. ERnout et Fr. Thomas, Syntaxe latine, Paris, Librairie C. Klincksieck, 1964, $\S$ 428; M. Bassols de Climent, Sintaxis latina, II, § 199 (5.a reimpr., Madrid, CSIC, 1976).

57 ERnout-Thomas, § 270, Bassols, II, § 201.

LXII, 3.0-4. -4 
Finalmente, en español medieval y clásico (menos usual en moderno) aun significó "ojalá» y regía subjuntivo (no he hallado correspondencia latina):

"Aun vea el ora que vos meresca dos tanto» (Cid, 2338), «Diz: 'jay! molyno rezio, avn te vea casado'» (JRuiz, LBA, $195 \mathrm{~d}$ ), «aun nunca Dios me diese otra pena" (Comedia Seraphina, apud Keniston, pág. 365).

En su valor como "también" o «incluso» ${ }^{58}$, según señalan las gramáticas, indica gradación conceptual presentando al último término de la serie explícita o presupuesta, sentido como 'culminación'; junto a ello, un claro valor concesivo (de donde surge la conjunción aunque). El rasgo básico del significado de aun, 'continuidad' o 'persistencia', se presenta aquí como continuación de la aplicabilidad de un elemento, o una oración, expresada de forma más o menos 'enfática': se afirma su realidad "a pesar de" otra cosa (expresada o no), y de ahí el sentido 'concesivo'. Los valores de 'continuidad' y 'concesivo' suelen ir unidos, aunque domine uno u otro según los elementos de la frase o el contexto. Es claramente concesivo cuando precede a un gerundio: «aun diciendo eso, no te creerán», o en la locución aun cuando: «no te lo pedí, aun cuando lo necesitaba»; o precediendo a si: "El prinçep Antinagora por njnguna ganançia, / avn si ganase el jmperio de Françia..." (Apolonio, $548 \mathrm{a}-\mathrm{b}$ ); en el primer caso puede considerarse variante combinatoria de aunque condicionada por el contexto, y en los otros dos combinación del valor concesivo con el temporal o el condicional. El mismo sentido claramente concesivo aparece en: «Es mayor de todas Asia $\tau$ meior; / avn cuemo es buena deuie ser meior" (Alexandre, 263 a-b, ms. O).

La presencia de aun con el valor descrito y aplicado a un elemento oracional se da muy pronto en castellano. Los contextos más usuales son los siguientes:

a) Como último término de una serie coordinada, o yuxtapuesta, en forma afirmativa o negativa:

"...a prouecho de nuestros parientes viuos $\tau$ aun de los muertos" (Doc. Ling., n.o 305, Cuenca, 1184), “Aun Castiella Vieja, al mi entendimiento, / mejor es que lo al" (FGonzdlez, $158 \mathrm{a}-\mathrm{b}$ : tras una gradación, donde España es mejor que Francia o Inglaterra, Castilla lo mejor de España, y Castilla la Vieja lo mejor de Castilla), «E maguer que en este tiempo

58 Para el problema de su carácter tónico o átono: Cuervo, Diccionario, s. v. aun; T. NAVARro TomÁs, «Palabras sin acento», en RFE, t. XII, 1925, págs. 335-375, y Manual, § 147; R. A. E., Esbozo, §§ $1.5 .4 a 9.0^{\circ}, 1.5 .4$ b, 1.6 .9 b 2.0 y 3.0; M. SECo, Diccionario, s. v. aum. 
era ya finado Jacob, e Josep su fijo e aun los otros fijos de Jacob e de Josep...» (GEstoria, 1." parte, Lib. XI, c. I), «Mal pasan ally los santos e aun Santa Maria» (P. López de Ayala, Rimado, 305 b), «Los catalanes, valençianos $\tau$ aun algunos del Reyno de Aragon fueron $\tau$ son grandes ofiçiales desta arte» (Santillana, Carta-Prohemio, XII), «Calças traygo, y avn borzeguies de essos ligeros que tu dizes" (Celestina, XII), «se derraman por los palacios, por los mesones, por las tiendas y aun por las iglesias» (Guevara, Menosprecio, apud Keniston, 500), "Pregunto io: han sido vtiles al mundo las poesias $\mathrm{i}$ aun las profecias?» (Góngora, apud B. Alemany, Vocabulario..., s. v.), «...de suerte que todas sus acciones y aun razones vayan revestidas de (...) magestad» (Gracián, Oráculo, 296), «...que ni aun los muertos están libres de las sospechas y aun envidias de los cortesanos" (Cadalso, Noches, 13); alternando con hasta: "Y asi las bases que las reciben como los capiteles que las coronan, y aun las plumas de los adornos de éstos (...), y en fin, hasta las dovelas de los arcos siguen exactamente los cortes de sus ángulos» (Jovellanos, Obras, III, 7); la alternancia con hasta permite incrementar la serie: «...pero de tan flojo carácter, que sus hijos, y aun los criados, y hasta el gato, hacían de ella lo que querían" (Galdós, Lo prohibido, 72), etc. $\$ 9$.

Partiendo de este tipo, encontramos aun precedido por la copulativa, aunque no forme una serie explícita con elementos anteriores (refuerzo expresivo que convierte a la conjunción en un cuasi-adverbio):

"E aun con todo esto, fazen algunas dellas muy grandes maldades (Libro montería Alfonso XI, I, Prólogo), «Y aun en este sentido es verdadera aquella paradoxa» (Gracián, Oráculo, 170), "¿Por qué ha de tener celos?... $\mathrm{Y}$ aun eso mismo debiera enamorarle más» (Moratín, $S i$ de las niñas, II, 16).

En las frases negativas, como es lógico, la secuencia es ni aun:

«...assi que nol pudo ella deffender, ni aun otro ninguno por ella» (Prim. Crón. Gral., c. 737), «...ya por no tener noticia de todas, ni aun de una décima parte de ellas...» (Feijoo, Teatro, III, vi), «...ni la pólvora, ni la imprenta, ni el dinero, ni aun la moda misma, tienen la fuerza irresistible...» (Hartzensbuch, Querer, apud Cuervo, Dicc., s. v. aun);

ni aun es mucho más normal que $y$ aun cuando, en frase negativa, no hay serie explícita:

"Commo vos podedes a $\mathrm{mj}$ por vna palabra rreprehender, njn avn por aquesto el obispo çiertamente non es escusado de corregir al pueblow (P. de Luna, Consolaciones, Lib. 5.०, c. 1.०), «Ni aun a vosotros no lo dixera si no me uviérades importunado» (J. de Valdés, Dialogo Lengua, 93)

59 Si en la serie el último elemento se entiende englobado en el anterior, es casi general la no presencia de la conjunción: "los hombres, aun los más cobardes, son capaces de ser héroesn; la presencia de $y$ sería poco admisible (igual ocurre con hasta e incluso). 
(en ambos ejemplos con redundancia negativa):

"...que después que aquí nos emparedaron, ni aun el canto de los pájaros habemos oído» (Cervantes, Celoso), "Pienso que ni aun los mismos que se interesan en apoyarla están acordes» (Feijoo, Teatro, III, ix), etc.;

como señala Cuervo, la fusión de los dos elementos es tan estrecha que a veces se antepone $y:$ : $Y$ ni aun lo es de las actuales sociedades» (Lista, Ensayos, 2). También indica Cuervo que en español clásico era frecuente el empleo sólo de aun en frases negativas:

"Pero avn con todo lo que he dicho no os despidays» (Celestina, XII), «Aun a los animales no se vedan las voces humanas (DHurtado de Mendoza, Guerra, Lib. I), "Y aun la igualdad no bastará" (Gracián, Oráculo, 153);

también en época posterior:

"Aun los reglamentos económicos no tienen jurisdicción sobre él» (Jovellanos, Obras, III, 254), "Aun esto de llamar necio al autor incógnito de un artículo, nunca pudiera ser personalidad" (Larra, Obras, I, 50).

b) Como refuerzo en correlaciones de valor adversativo, equivalentes a la fórmula más frecuente hoy no sólo... sino también (donde, igualmente, el ámbito de aplicación puede ser toda la oración o sólo un elemento):

«E non tan solamientre fueron departidos en los lenguajes, mas aun en las uoluntades" (Prim. Crón. Gral., c. 1), «E non solamente aqueste de religioso, mas aun los otros estados pueden aver...» (Villena, Doze trabajos, c. 4.0), «...no solo la necessidad que nuestra comun patria tiene (...) pero avn en particular vuestra misma persona...» (Celestina, Prólogo), «...nos déis cuenta, no solamente de lo que avéis escrito, pero aun de lo que dello depende" (J. de Valdés, Diálogo Lengua, 49), «...no sólo a rústicos y niños, pero aun a venerados sacerdotes..." (Feijoo, Teatro, III, 1);

posteriormente, se encuentra con menos frecuencia.

c) Delante de elementos oracionales, sin conjunción precedente, y sin formar parte de serie, aunque ésta se presuponga (o, como afirmaba la gramática tradicional, se elida: 'gradación tácita'). Los ejemplos son muy numerosos; seleccionaremos algunos ante sujeto:

"Aun tú, que dixiste a los tus servidores» (JRuiz, LBA, 7 a), "Quant dulçe es la sçiençia, muy catholico prinçipe, avn aquel lo siente que nunca aprendio» (A. de Cartagena, Traducciones, en Crestom., 570.6-7), «Aun yo, con ser lo que soy, parezco otra» (Sta. Teresa, Vida, apud 
Cuervo, Dicc., s. v.), "Aun lo lindo, si sobresale, es descrédito» (Gracián, Oráculo, 278), «Aun la noche (...) es menos gustosa, porque en algo se parece al día" (Cadalso, Noches, 38), "Aun los que no podían oír lo que decía celebraban su gracia» (Galdós, Lo prohibido, 157), «Porque, aun la vida beata (...) ¿estará, si es vida, fuera del tiempo...?» (A. Machado, Juan de Mairena, 71);

su frecuencia sigue siendo notable, aunque en el habla coloquial y popular parece retroceder ante hasta o incluso, ya que la diferencia semántica (el sentido 'concesivo' de aun) se anula en muchas ocasiones ante el predominio del valor de 'continuidad' enfática, en el que concurre con las otras dos partículas.

Como hemos visto, el elemento que introduce aun supone una oposición con otros anteriores, explícitos o presupuestos ${ }^{60}$ (el hecho de afirmarse, a pesar de esa oposición, es lo que proporciona el énfasis); mucho más raro es que la oposición se dé entre dos elementos introducidos igualmente por aun, como se ve en este caso del Cid (no he encontrado otros): "Si conuusco escapo sano o biuo, / aun çerca o tarde el rey querer m'a por amigo" (v. 76).

Lógicamente, aun se presenta también delante de verbos; al igual que ocurría con hasta, en estos casos su ámbito se extiende a todo el sintagma verbal; si como adverbio temporal puede ir delante o detrás del verbo ("aún no ha venido" - «no ha venido aún»), en este otro valor se encuentra casi siempre delante del verbo, como ya señaló Pottier:

«En cabo sy oujeses liçençia o vagar, / avn querrias de tu grado en las nuues pullar» (Alexandre, $1900 \mathrm{a} \cdot \mathrm{b}, \mathrm{ms} . \mathrm{P}$ ), «Et dizen (...) que paresçio y Santiago (...) et que andaua y con el vna ligion de caualleros blancos; et aun dizen que angeles vieran andar... (Crón. particular SFernando, c. 1044), "Nunca me assente, ni avn junte, por Dios, los pies» (Celestina, XII), "...lo dicho basta, y aun sobra" (J. de Valdés, Diálogo Lengua, 151), "...tapando los agujeros de donde aun tenía sospecha que se pudiera criar» (M. Alemán, Guzmán, Lib. III, c. IX), «...que es todo para la felicidad, y aun ajusta la cordura. Da en tirana: ni se contenta con la especulación, sino que obra y aun suele señorearse de la vida” (Gracián, Oráculo, 24), «Pepe no obedecía. Aun se enojaba un poco» (Galdós, Lo prohibido, 160), «Encontramos, en efecto, algunas imágenes adecuadas (...) y aun logramos otras imágenes felices» (A. Machado, Juan de Maina, 72).

60 Cfr. B. Potrier, «Problemas relativos a 'aun, aunque'», en Linguitstica moderna y filología hispánica (versión española de M. Blanco AlvarRz), Madrid, Editorial Gredos, 1968, págs. 186-193. 
Los valores y contextos en que aparece son los mismos que ante sintagma nominal. En ocasiones, aparece separado de la oración que modifica:

«Y aun, si yo pensara no enojaros, yo os prometo...* (J. de Valdés, Dialogo Lengua, 182), «pienso darlo a todos los que querrán, y aun, si me pareciere, lo haré imprimir» (ibid., 184).

Frente a lo que ocurría con hasta, se encuentra a veces aun en comienzo de frase, delante de un sintagma nominal, pero la interpretación semántica nos lo impone como refiriéndose a toda la frase (el énfasis por contraposición se entiende, no sobre un solo elemento anterior, sino sobre toda una oración); otras, la interpretación es ambigua entre ambas. El distinto comportamiento de hasta y aun se explica por su diferente origen: la primera era preposición, por lo que tiende a agruparse con sintagmas nominales; el segundo, adverbio (temporal) que delimita el proceso verbal. Este hecho se comprueba cuando, al trasladar aun delante del verbo, no se produce ningún cambio de sentido ${ }^{61}$. Creemos que se da en casos como:

«Aun todos estos duelos en gozo se tornarán» (Cid, 381), «Avn grand amor nos faze el Çid Campeador, / quando desondra de sus fijas no nos demanda oy» (ibid., 3164), aTanto tenie Asia cuemo todo lo al, / aun vn poquiello passa de la sennal» (Alexandre, $262 \mathrm{a}-\mathrm{b}, \mathrm{ms}$. O; en el ms. $\mathrm{P}$, 267 a-b: «...avn pasa poqujllo de la señal»), «Pero fio de Dios que avn tienpo verna...» (JRuiz, LBA, 683 a), «...y aun la lisonja (...) se extendió a llamarle Alteza» (DHurtado de Mendoza, Guerra, Lib. II).

5.2. La otra partícula de valor y empleo semejantes a las anteriores es incluso. Su fijación en tal uso es relativamente moderna. Corominas ${ }^{62}$ señala que su valor adverbial falta aún en el Diccionario académico de 1884. Ya lo había recogido Cuervo en la Nota 143 a la Gramática de Bello: al igual que otros participios y adjetivos frecuentes en construcciones absolutas (salvo, excepto, durante, mediante, etc.) se había inmovilizado, perdiendo la primitiva concordancia con el sustantivo a que acompañaba; sin embargo, ésta puede encontrarse todavía, aunque de forma esporádica $y$ en lenguaje arcaizante, en el siglo $x x$ :

61 En cambio: aaun yo parezco otrax: hay otras personas a quienes ocurre eso, y también yo me incluyo; ay aun logramos otras imágenes: nosotros hicimos tal y cual cosa, y también el lograr imágenes.

62 Diccionario Crítico Etimológico de la Lengua Castellana, 4 vols., Madrid, Ed. Gredos, 1954; como adverbio y preposición incluso se recoge por primera vez en la 15.a ed. del DRAE, de 1925. 
«...instituida heredera en el remanente, inclusa la nuda propiedad...* (A. Maura, Dictámenes, 1929, T. 2, pág. 47) ${ }^{63}$.

Subsistió con valor verbal, de participio, junto a la forma analógica incluido, - $a$, -os, -as (única usada en los tiempos compuestos), y como segundo participio de incluir se halla en los Diccionarios (desde Covarrubias a la edición de 1970 del DRAE).

Junto a él existía el adverbio latino inclusive (del latín escolástico), cuyo valor es el mismo desde la definición de Covarrubias: indica que el elemento a que se une se considera dentro de una secuencia; generalmente va detrás: "de aquí al domingo inclusive», "hasta el día treinta inclusive». Es probable que la existencia de esta forma influyera en la adverbialización de incluso: la relación de forma léxica y de contenido semántico es demasiado estrecha como para dejar de suponer una actuación en tal sentido.

Cuando acompaña a un sustantivo en masculino singular, es difícil decidir si corresponde ya a nuestro empleo actual, aunque el sentido parece indicarlo así en muchas ocasiones:

"Con respecto a caminos no hay otra novedad (...) que el seguir los más de ellos interceptados, incluso el de las reformas» (Larra, Obras, II, 18).

Pero ya en Larra se encuentra sin variación ante una serie de sustantivos yuxtapuestos, que quizás exigieran la forma concordada ${ }^{64}$ :

«...deben disfrutar o no gratis de todas las funciones que en el tal local puede dar la empresa, incluso alumbrado, alfombra, mesas de juego, ambigú y demás» (Obras, II, 42).

Ya en la 2.a mitad del siglo xIX empieza a ser frecuente en forma inmóvil:

«Doña Araceli, sin la menor ironía, elogió el arrope y las gachas y todo lo demás, incluso las empanadas» (Valera, Ilusiones, 139), «...hacían en ella más vehemente toda pasión, incluso la del amor" (íd., Comendador Mendoza, apud N. 143 de Cuervo a la Gram. de Bello), «Todo me parecía bien, incluso la persona de doña Javiera” (Galdós, Amigo Manso, apud M. Seco, Dicc. dudas, s. v.), «Doña Victoria hipotecó al Pobrecito esta posesión del Collado, con todas sus pertenencias, incluso ganados, ajuar, mueblaje... (R. Pérez de Ayala, Novelas, 155).

63 Del fichero del Seminario de Lexicografía de la R. A. E.

64 La cual, por otra parte, existe en Larra: «todos los actores, inclusos los que no la representaron" (Obras, II, 103). 
En el siglo actual se ha convertido en un elemento de cada vez mayor frecuencia de empleo, y, por lo que se puede observar, en todos los niveles sociales. En este sentido, parece estar ocupando parte del dominio de aun, que, como hemos visto, fue el general en español medieval, clásico, y comienzos del moderno.

En la competencia entre las tres formas, no se ha producido, al menos de una manera clara, una distribución de sus significados que impida la cuasi-sinonimia actual (sinonimia que, como ocurre en general en la lengua, puede terminar con la vida de alguna de las formas concurrentes). Si bien en hasta parece predominar la idea de 'límite enfático', en aun la de 'concesivo' y en incluso la de integración en una serie, lo cierto es que las tres pueden manifestar, en general, los tres valores. Por otro lado, en cuanto a su reparto en estratos sociolinguísticos, aun parece irse reduciendo al lenguaje literario, quizás con un cierto sabor "cultista (que puede llevarlo a ser un elemento «arcaizante»), mientras que los otros dos muestran una completa vitalidad en todos los sectores: de ellos, hasta, probablemente por su carácter más 'enfático' y 'expresivo', parece ser el más popular (al menos, es el que más se oye en el habla andaluza no cultivada).

Hay también factores de orden lingüístico que operan en la selección de estas tres partículas: incluso no presenta los problemas de homonimia con otros empleos diferentes (con valor de participio es prácticamente inusitado hoy), por lo que su consolidación parece asegurada. En este sentido, puede aparecer, con el mismo valor que en otros contextos, ante oración temporal introducida por cuando: «...melancolía, que asimismo se advierte en la plaza, incluso cuando el toro cae muerto" (Díaz-Cañabate, Historia de una tertulia, 184: del Sem. de Lexic. de la R. A. E.); en cambio, aun cuando se ha fijado ya como conjunción concesiva, equivalente a aunque, por lo que su presencia en una frase como la anterior sería ambigua, interpretable o como locución conjuntiva (valor unitario) o como aun más un elemento. Por otra parte, en ciertos contextos hasta puede ser también ambiguo entre su valor preposicional o el 'enfático': "corrió hasta donde dijimos»; esto no ocurre con incluso: "corrió incluso donde dijimos». Finalmente, el ámbito en que aun se mantiene con firmeza es el de las oraciones negativas (donde hasta no aparece normalmente, según ya vimos); sin embargo, aquí también está sufriendo el empuje de incluso, aunque no se haya generalizado todavía en tales secuencias: 
"Las palabras no es necesario, ni incluso de buen gusto, terminarlas» (Cela, Judios, moros y cristianos: del Sem. de Lexic. de la R. A. E.) ${ }^{65}$.

Por otro lado, en las frases negativas es muy frecuente la forma ni siquiera:

"¿ni siquiera una onza de oro le han querido adelantar...?» (Moratín, Sí de las niñas, I, 6), «¿No corren aquí siquiera los caballos? (...) Ni siquiera los caballos" (Larra, Obras, I, 269), "Apenas había en Villabermeja, ni siquiera en espíritu, tres o cuatro familias hidalgas» (Valera, Ilusiones, 79), «No podemos probar que nada permanezca idéntico a sí mismo, ni siquiera nuestro pensamiento" (A. Machado, Juan de Mairena, 146).

Ni siquiera es más corriente en el coloquio que ni aun.

Finalmente, a diferencia de hasta y aun - muy rara es la posposición de aun al elemento que modifica:

«que ayer maravilla fui, / y sombra mía aun no soy» (Góngora, Letrillas, apud B. Alemany, Vocabulario, s. v.),

incluso puede posponerse al elemento a que se aplica, normalmente cuando funciona éste como aposición bimembre (¿o yuxtapuesto?) respecto de otro elemento, especificándolo o restringiéndolo: «los hombres, los cobardes incluso, son capaces de arranques generosos», "sale a pasear todos los días, los que llueve incluso"; no obstante, es orden menos frecuente. Por otro lado, puede funcionar como elemento referido a toda la oración, separado de ella mediante pausas, al principio, en medio o al final:

«...desde luego, si gusta, puede, incluso, desnudarse delante de mí» (Muñoz Seca, Alfiler, I, 29: del Sem. de Lexic. de la R. A. E.), «Estaba acostumbrada a obedecer, a ser avasallada, a ser menospreciada, inclusow (E. Quiroga, Enferma, 44: ibid.), "Incluso, llegó a decir que todo era falso».

Este tipo de construcción no era posible con hasta (por su origen preposicional) y apenas se daba con aun.

5.3. La inclusión de estas partículas, y algunas otras, en una u otra de las 'partes de la oración', 'clases de palabras' o 'categorias gramaticales primarias' plantea bastantes problemas: prueba de ello son las vacilaciones, e incluso contradicciones, que encontramos en las gramáticas y diccionarios de español cuando las analizan. En este sentido,

65 M.a Luisa Rivero, en Estudios, pág. 107, da como agramatical «ni incluso si me lo explicas, lo comprenderéx; creo, más bien, que es poco usual. 
se han escogido dos tipos de soluciones: a) incluirlas en algunas de las categorías existentes; b) crear una nueva categoría intermedia; el análisis, según el tipo a), ha vacilado entre adverbios, preposiciones o conjunciones.

Así, Cuervo, en la Nota 143 a la Gramática de Bello, parece considerar a incluso preposición «imperfecta»: su uso es idéntico al de excepto; pero Bello, ante excepto y salvo, dudaba entre si eran preposiciones o conjunciones ( $\mathrm{y}$, como veremos, a hasta y aun los consideraba 'cuasiafijos'). Hanssen ${ }^{\text {to }}$ considera a incluso preposición (como excepto, durante, etc.), pero a hasta y aun adverbios de la serie de los 'cuasi-afijos'. Por su parte, R. Seco ${ }^{67}$ vacila en analizar a salvo, excepto, incluso como preposiciones o conjunciones, pero considera a aun como adverbio de cantidad, frente a aún temporal (no obstante, da la equivalencia aun = 'incluso, hasta'). En M. Seco ${ }^{68}$ hay una curiosa contradicción: mientras considera a hasta como adverbio con el significado de 'inclusive', cree a aun, incluso (y salvo, excepto, menos, etc.) preposiciones, con pronunciación átona. Pottier ${ }^{69}$ no establece diferencia al considerar todos estos elementos 'relatores', en este caso en el campo 'nocional'. Alcina y Blecua ${ }^{70}$ parecen analizar hasta e incluso (junto con excepto, salvo, etcétera) como preposiciones, frente a aun como adverbio (aunque reconocen sus equivalencias de sentido).

Las clasificaciones de algunos diccionarios son también bastante inconsecuentes: la edición de 1970 del DRAE analiza a aun como adverbio de modo (o temporal), a hasta (acepción 2 ) como conjunción copulativa (equivaliendo a también o aun), y a incluso como adverbio de modo (acepción $2=$ "con inclusión de, inclusivamente»), o preposición o conjunción (acepción $3=$ «hasta, aun»). Más coherente parece ser María Moliner ${ }^{71}$, quien considera adverbiales todos estos empleos. Por su parte, el Diccionario de dudas... de M. Seco repite lo que hemos visto en su Gramática..., aunque habla de incluso como adverbio oracional en frases como «incluso puedes telefonearle».

En otros autores predomina un criterio más uniforme: Keniston ${ }^{72}$ los considera adverbios (no trata de incluso, ya que en tal uso no existía

66 Gramática, §§ 460, 497, 632, 729 y 736.

67 Manual de gramática española (revisado y ampliado por M. SECo), 8.a ed., Madrid, Ed. Aguilar, 1966, págs. 114, 276 y 294.

68 Gramática, pág. 178, n. 1.

69 Gramática, págs. 35-36, y "Problemas...", passim.

70 Gramática española, Barcelona, Ed. Ariel, 1975, §§ 4.9.4, 6.2.1, 7.3.3 d, 7.3.6 b. 7.8.3.2 a, 8.1.1.3.

71 Diccionario de uso del español, 2 vols., Madrid, Ed. Gredos, 1966.

72 The Syntax, págs. 6, 500, 568, 586. 
en el siglo xVI), y habla de una clase de adverbios, los distinguishing adverbs, caracterizados por poder distinguir cualquier palabra o frase de la oración. Alarcos ${ }^{73}$ excluye a hasta del inventario de preposiciones españolas, ya que en frases como "hasta le insultón contiene un morfema casual que puede ser regido por un verbo, y, por tanto, es 'adverbio' (no obstante, creemos que en "voy hasta Madrid", etc. ha de seguir analizándose como 'preposición'). También considera a hasta adverbio Hdez. Alonso ${ }^{74}$.

Estas vacilaciones ya se dan en el análisis de formas latinas antecedentes de las que estamos tratando: adhuc o etiam aparecen clasificados como adverbios o conjunciones (en latín no se las puede considerar preposiciones, ya que no rigen caso); al mismo tiempo se habla de usos adverbiales de ciertas preposiciones, cuando no lleva el sustantivo el caso que exigen (en esto, muestran un resto de su primitivo origen como adverbios).

Por su parte, otros autores, ante los problemas que plantean estas partículas, forman una nueva categoría a caballo entre adverbios, preposiciones y conjunciones, pero sin confundirse con ellos. Así, Bello ${ }^{75}$ habla de una clase especial de elementos a los que llama 'cuasi-afijos' o 'partículas prepositivas', y en los que incluye, además de hasta y aun, a como (en: «Encontró Don Quijote con dos como clérigos o estudiantes»), casi (en: «casi exánime», "casi le mata», etc.), medio (en: «...medio mujer y medio pez», "...se medio corrió el capellán»), etc. Ya hemos visto que Hanssen ${ }^{76}$ habla de este tipo, refiriéndose a Bello. Sin embargo, es grupo algo heterogéneo, ya que, si bien casi, como, medio, funcionando como elementos prefijales, pueden modificar el contenido del elemento a que acompañan, esto se realiza sobre su significado léxico, y no sobre la relación sintáctica en que están insertos; aparte de que en contextos normales para hasta o aun no son posibles esos otros: "«casi los niños vinieron", "«trabajaban medio con frío", *«mataron como a los inocentes» («los mataron como a los inocentes» tiene

73 Gramática estructural, pág. 83.

74 «El adverbio», pág. 64.

75 Gramática, $\S \S 1217,1231,1236,1252$; sigue esta opinión C. CoRrales, "Sobre el sujeto con preposición», en Estudios ofrecidos a Emilio Alarcos Llorach, 2, Universidad de Oviedo, 1978, págs. 65-78, para quien no sólo hasta es 'partícula enfática', sin valor gramatical, sino también entre, en los usos que examinamos en el § 3; cfr. también: G. GafNZA, "¿Sujeto preposicional? Un problema de límites», en Estudios filológicos, Univ. Austral de Chile, núm. 9, 1973, págs. 71-88, y J. A. MarT1NEZ, "Entre tú y yo»: ¿sujeto con preposición?», Archivum, XXVII-XXVIII, 1977-78, págs. 381-396.

76 Gramática, § 632. 
estructura muy distinta). Algo semejante encontramos en el Esbozo ${ }^{7}$, en donde se nos habla de las 'partículas incluyentes' aun, hasta e incluso y de las 'excluyentes' excepto, menos y salvo; se relacionan por el significado: inclusión (/ exclusión) en una serie, o participación (/ noparticipación) en algo, y por el comportamiento sintáctico: pueden regir toda una serie compleja de complementos, tales como nombres, pronombres, verbos, fórmulas con preposición, etc. Sin embargo, nos parece evidente que el comportamiento sintáctico de unas y otras partículas no es idéntico; hay contextos en los que pueden conmutar: "Todos vinieron, aun-hasta-incluso-excepto-menos-salvo Juan"; pero en otros no: "Aun-hasta-incluso los niños lo saben" / * «xcepto-menossalvo los niños lo saben», "Juan aun-hasta-incluso se enojaba un poco» / * «Juan excepto-menos-salvo se enojaba un poco»; los elementos introducidos por las 'partículas excluyentes' sólo pueden ir en aposición restrictiva respecto a un elemento explícito anterior.

5.4. A la hora de establecer el tipo de categoría en que las partículas que estamos tratando pueden ser incluidas, hay que precisar si sus caracteres sintácticos, que hemos ido viendo, se conforman o no con los de alguna clase preexistente.

Desde este punto de vista, resulta claro que aun, hasta e incluso no pueden considerarse preposiciones, si nos atenemos al concepto comúnmente admitido de 'preposición', resumido en el $\S 1$. No señalan la dependencia del sintagma que introducen respecto de otro elemento: ese elemento cumple la misma función sintáctica que tendría sin la presencia de la partícula, por lo que ésta no es índice funcional ni de rección. Por otro lado, aparecen ante verbos en forma personal con el mismo valor que ante sintagmas nominales, y en la misma forma; en ese contexto, las preposiciones exigen el nominalizador que y trasponen toda la oración a una de las funciones propias de los sintagmas nominales ${ }^{78}$ : compárense "hasta se emborracharon" / "hasta que se emborracharon", donde hasta funciona como verdadera preposición sólo en la segunda frase. Por supuesto, estas partículas pueden modificar a toda una oración que ya presente los índices apropiados: "dijeron incluso que no tenían dinero", "grita hasta para que le abran la puerta", etcétera; no es frecuente aun ante una oración en función de objeto directo, por la posible confusión con la concesiva aunque (donde la estructura es diferente), pero he encontrado algún ejemplo antiguo:

$\pi 7$ Cfr. $\S \S 1.5 .4 .9 .0$ n. $15,1.6 .9$ b 3.०.

78 Cfr. Alaroos, Estudios, págs. 192-194. 
"Vino al padre santo a merced le clamar, / que deñasse por elli al Criador rogar: / si essa vez sanasse no irié a furtar, / aun que jurarié desto non lo falsar» (Berceo, SDomingo, 427). Pero no son ellas las que señalan la función; además, se encuentran ante sujeto, función que en español no presenta índices de este tipo.

También presenta objeciones claras su análisis como conjunción. No se puede considerar como tal en frases como: «Aun-hasta-incluso los niños lo saben", donde no unen el sintagma que introducen a otro anterior, ya que no existe, y por tanto no hay tal 'conjunción' o 'coordinación' de elementos. Es cierto que la gramática tradicional hablaba de elisión de la serie anterior, lo cual justificaría la presencia de estas partículas conjuntivas; pero nos parece que la coordinación, como fenómeno sintáctico, ha de establecerse entre elementos presentes en el discurso, y sólo se debe recurrir al concepto de 'elipsis' en los casos absolutamente imprescindibles ${ }^{79}$; por otra parte, también en los casos en que $y$ inaugura una frase sin aparente conexión con otra precedente, se ha hablado de su 'adverbialización', con un valor 'enfático' que supera la simple coordinación ${ }^{80}$. En los casos de serie donde el último elemento va introducido por y aun-hasta-incluso la conjunción es, evidentemente, $y$ (o ni, etc.); no se debe considerar como locución conjuntiva, ya que el valor de la partícula es el mismo que cuando no hay tal serie. Más problemático es el caso de construcciones como: "Vinieron los viejos, los jóvenes, incluso los niños», "lo elogió todo, hasta las empanadas", "la humanidad, aun la parte más desfavorecida, no pierde la esperanza»; este tipo de construcciones es el más próximo a un análisis como 'conjunciones' de tales partículas, no sólo por el valor semántico 'inclusivo' que poseen en todas sus apariciones, sino por el hecho de enlazar elementos del mismo nivel sintáctico. Sin embargo, hay razones para no seguir tal análisis, también en estos casos: en primer lugar, una razón de coherencia, ya que si en otros contextos no era analizable como tal, por motivos sintácticos, en éstos, donde su valor es idéntico, tampoco hay por qué hacerlo; en segundo lugar, puede hablarse de una serie formalmente yuxtapuesta, aunque con enlaces lógicos, estructura normal en la lengua, y que responde a intenciones significativas precisas (cfr.: "vinieron los viejos, los jóvenes, los niños»); finalmente, hay que señalar que este último tipo se da sobre todo cuando el sintagma intro-

79 Por ejemplo, cuando la conjunción une elementos no equivalentes: «Juan trabajó, $y$ con mucho entusiasmo», etc.; cfr. ANA M.a BaRRenecheA, "A propósito...», passim; ANA M.a ECHAIDE, «La coordinación adversativa en español. Aspecto sincrónico", RFE, t. LVII, 1974-1975, págs. 1-33.

80 Bello, Gramática, § 1286; Alcina-Blecua, Gramática, § 9.1.5. 
ducido por alguna de nuestras partículas se considera englobado semánticamente en el anterior, es un subconjunto dentro del conjunto referido por el elemento anterior; su intencionalidad significativa es la de precisar, especificar, restringir, o marcar la inclusión del subconjunto en lo que se afirma del conjunto total; formalmente, puede analizarse como una aposición bimembre de un sintagma (nominal o no) respecto de otro de su misma categoría, reforzado por alguna de las partículas aun, hasta o incluso; además, no hay verdadera coordinación en estos casos ya que si el primer elemento, cuando es sujeto, va en singular no se exige concordancia de número con el verbo: «el país, incluso las regiones pobres, no pierde la esperanza». Por último, habría que señalar que el contenido semántico de estas partículas sobrepasa ampliamente a lo que es propio de las conjunciones coordinantes.

De las dos alternativas que quedan: incluirlas en los adverbios o crear una nueva categoría, nos inclinamos por la primera. Un grupo como las 'partículas incluyentes' del Esbozo (ya hemos visto que las 'excluyentes' tienen comportamiento distinto) es demasiado pequeño para ponerlo al mismo nivel que sustantivos, verbos o adverbios; pero, más importante que esto, los caracteres sintácticos de estas partículas coinciden con los de elementos clasificados tradicionalmente como 'adverbios'. Es cierto que la categoría del 'adverbio' es una de las peor definidas dentro de la Lingüística, e incluye elementos muy heterogéneos ${ }^{81}$; pero las partículas analizadas tienen como función modificar o incidir sobre la relación sintáctico-semántica establecida entre el sintagma a que acompañan y el verbo o el elemento que lo rija (caso de acompañar a un sintagma nominal), o sobre el verbo, el sintagma predicativo o toda la oración. Siguiendo a Alarcos, no funcionan autónomamente como 'aditamentos', pero pueden incluirse dentro de los valores 'nocionales' (frente a los 'situacionales', que enmarcan espaciotemporalmente todo el enunciado: aqui, entonces, etc.), y dentro de aquellos que, como el mismo Alarcos señala, pueden incidir sobre el

81 Uno de los mejores estudios sobre el adverbio en español es el de E. Alarcos, "Aditamento, adverbio y cuestiones conexas", en Estudios, págs. 219-253; el ya citado de C. Hdez. Alonso, "El adverbio»; P. CARbonero, "Criterios para una caracterización funcional de los adverbios", en $R E L, 8,1,1978$, págs. 169-197; P. DoMf́ngUEZ DE Rodríguez-PASouÉs, "Morfología y sintaxis de los adverbios en -mente», en III Congreso Internacional de Hispanistas, México, 1970, págs. 293-303; A. LóPEz GARcta, Elcmentos de Semántica dinámica. Semántica española, Zaragoza, 1977, en especial cap. 9, con abundante bibliografía; sobre el francés, pero con gran interés para el español, Ole Mørdrup, Une analyse non-transformationnelle des adverbs en -ment, Etudes romanes de l'Université de Copenhague, Revue Romane, numéro spécial 11, 1976, y "Sur la classification des adverbs en -ment», en Revue Romane, XI, 2, 1976, págs. 317-333. 
núcleo del predicado o sobre uno de sus elementos: «Quizá venga Juan", interpretable como "lo que probablemente hará Juan será venir» (incidencia sobre el verbo) o "probablemente será Juan el que venga" (incidencia sobre el sujeto). Por otra parte, se ha señalado el hecho de que muchos adverbios de modo o manera no matizan el significado léxico del verbo, sino que inciden en la relación Sujeto-Predicado, por ejemplo, y se refieren así indirectamente al sujeto: "Juan trabaja lentamente» (= "Juan es lento al trabajar»); de ahí, incompatibilidades semánticas del tipo: "Juan me golpeó astutamente» / *«la piedra me golpeó astutamente»; o ambigüedades como la cle "Juan me golpeó estúpidamente» = "Juan fue un estúpido al golpearme» (pero sin calificar el modo de la acción) / "la forma de golpearme de Juan fue estúpida»; y diferencias del tipo: "Juan, amablemente, me contestó" / «Juan me contestó amablemente», señaladas por el orden de palabras y la entonación. A esto aluden las clasificaciones actuales de 'adverbios oracionales', 'orientados al sujeto', 'orientados al oyente', 'de manera', etcétera, $\mathbf{u}$ otras semejantes; en todas late la misma consideración: el adverbio no es ya sólo el "elemento que califica al verbo, al adjetivo o a otro adverbio" (base de la 'función terciaria' señalada por Jespersen y que, efectivamente, cumplen muchos adverbios), sino un elemento que incide en las funciones contraídas por los constituyentes de la oración.

Dentro de esto, y en un grupo numeroso de adverbios que tienen como ámbito de aplicación un constituyente oracional (más que una unidad léxica), podemos considerar a aun, hasta, incluso, con las particularidades sintácticas combinatorias que hemos encontrado al analizarlos. Se caracterizan, además, por no realizar 'función terciaria' propiamente dicha, es decir, no modifican el contenido léxico del adjetivo o adverbio que puedan acompañar: compárense: «Ese perro parece hasta inteligente», "lo hizo incluso honradamente" / "Ese perro parece enormemente inteligente», "lo hizo muy honradamente».

Los adverbios o locuciones que presentan rasgos semejantes a estas partículas son numerosos: Keniston los denominó distinguishing adverbs. La diferencia fundamental radica en que su orden es menos estricto que el de aun, hasta e incluso: mientras éstos preceden en general al elemento a que se aplican, esos otros adverbios pueden ir delante o detrás, o separados (en condiciones que habría que fijar); sólo la interpretación semántica, ayudada por el contexto, nos determinará su ámbito de aplicación. Citaremos ejemplos de algunos, espigados a lo largo de la historia del español: 
Solamente (-mientre, etc.):

"Estos atales non yerran solamiente contra el principe...» (FJuzgo, Primer título, IX), «...que cauallero de quantos de los cristianos eran no murio $y$, fueras aquel solamiente que perdonar non quiso» (Crón. particular SFernando, c. 1044), "¡Como si solamente el amor contra él asestase sus tiros!» (Celestina, I: aplicado a contra él);

y ejemplos muy numerosos en todas las épocas del idioma;

\section{Señaladamente:}

"Era omne que amaua mucho los gentiles, $\tau$ sennalada miente los de tierra de Caldea» (Lapidario, Prólogo), «Et por que todos los omnes, $\tau$ señalada mente los moços, quieren mas conplir su uoluntad.... (DJManuel, Libro Estados, I, LXXXV), «E assy las aues (...) buscan su vida $\tau$ su mantenjmjento, $\tau$ senalada mente las aues buscan su vida enla morada del jnujerno $\tau$ del verano" (PLópez de Ayala, Cetrería, XLV), etc.

\section{Mayormente:}

"Mandamos que todos los romeros et mayor mientre los que uinieren en romeria a Sanctiague..." (Fuero de SDomingo Calzada, IV, XXIIII), "En aqueste trabajo puede qual se quier de los estados del mundo aver e tomar dotrina a su mejoramiento e conservaçion. Mayormente el estado de religioso...» (Villena, Doze trabajos, c. 4..$^{\circ}$, "¿Qual hombre ay tan loco y fuera de razon que no fuelgue de ser visitado, mayormente de mugeres?" (Celestina, XVIII), "...ay algunos los quales de ninguna manera podemos escusar, mayormente en las partes pequeñas» (J. de Valdés, Diálogo Lengua, 178), «...sino que a todos se comunicasse, mayormente siendo sin perjuyzio" (Lazarillo, Prólogo), etc.

\section{Especialmente:}

"Ca sy non se deleytase enlas nobles doctrinas de sçiençia, espeçialmente en aquellas que guian...» (A. de Cartagena, Traducciones, en Crestom., 571.47-48), "Con esto andauase todo el mundo tras él, especialmente mugeres» (Lazarillo, I), "Todo parece aconsejarnos, y muy especialmente a nosotros..." (A. Machado, Juan de Mairena, 164), etc.

\section{También:}

"Y tambien yo tenia mis questiones con los que tirauan piedras a los paxaros" (Celestina, XII), "Que si se miente con la palabra, también con las cosas" (Gracián, Oráculo, 154), "También aquella resolución de Urbano la consideró natural» (R. Pérez de Ayala, Novelas, 70), « ¿También usted necesita un librito?» (A. Machado, Juan de Mairena, 85), etc. 


\section{Tampoco:}

*Ni con la tía Araceli he querido hablar de proyecto de boda. Tampoco la tía me ha hablado» (Valera, Ilusiones, 149), «Simona, con mansedumbre, dijo que tampoco ella cenaba y que se iba a acostar también» (R. Pérez de Ayala, Novelas, 68).

\section{Particularmente, en particular:}

«...no nos ha querido decir una palabra de su composición, de su representación, de sus reformas, y en particular de la enmienda que haya podido haber» (Larra, Obras, I, 39), «Yo creo que el decir, particularmente de estos últimos, muchos defectos que tienen...» (íd., 40).

\section{Acaso:}

«En este punto, acaso yo soy más escrupuloso que otros muchos (...) Acaso éste es ya un achaque de mi vejez (Jovellanos, Obras, III, 290), "Acaso nosotros pudiéramos comprenderlo mejor» (A. Machado, Juan de Mairena, 250), etc.

Otros adverbios que pueden entrar en este grupo son apenas, precisamente, principalmente, (ni) siquiera (ya hemos apuntado su competencia con ni aun en las frases negativas), o locuciones adverbiales como por lo menos, en general, etc. Es también posible que aun atraiga a este grupo a su cuasi-sinónimo todavia; es sabido cómo pasó del significado 'siempre, constantemente' (en época medieval y siglo xvI, sobre todo) al de 'aún, hasta cierto momento', en los siglos XVI-XvII (aunque Corominas cita el v. 374 a del Apolonio con tal valor: «Preguntól' el mancebo todavía dubdando»), y al de 'no obstante, con todo eso', sobre todo en correlaciones de tipo concesivo, y frecuente desde el siglo xvi; como vemos, vuelven a unirse los valores de 'continuidad' y 'concesivo' (o 'adversativo'). Pero la atracción de aun-aún se ha fijado en su empleo en comparaciones: "todavia mayor», "es más hermosa todavia», etc.; en su empleo en frases con el pronombre otro, o aplicada a un elemento de la frase y suponiendo continuación: "voy a decirte todavía otra cosa», "no voy a hacer más preguntas... Bueno, sí, una pregunta todavia», fáciles de documentar en el habla actual.

5.5. El caso de excepto, menos y salvo presenta características diferentes, según vimos en el § 5.3: no aparecen directamente ante verbos en forma personal, ni ante sintagmas no enlazados con otro anterior, por lo que no pueden unirse a aun, hasta, incluso. Sin embargo, hay que hacer algunas puntualizaciones: en primer lugar, menos, ele-

LXII, 3.0.4. -5 
mento de muy amplias posibilidades funcionales, se encuentra en ocasiones como último elemento de una serie, con un sentido de 'énfasis negativo', ante cualquier constituyente oracional:

«...otras cosas tales que nin a prinçipe real e menos a catolico christiano convenían» (FPérez de Guzmán, Generaciones, en Crestom., 549.23-24), "Por çierto aquestos atales non an leido e menos entendido lo que Lucano escrive» (Villena, Doze trabajos, c. 4. ${ }^{\circ}$ ), «Nadie puede decir eso, y menos tún, etc.;

en estos contextos, menos puede incluirse en el grupo de adverbios que hemos señalado más arriba.

Pero junto a esto presenta otro sentido de 'exclusión' en el que coincide con excepto y salvo: "Todos estaban contentos, excepto-menossalvo tú»; en este tipo de frases se limitan a señalar que un determinado elemento no debe incluirse en el conjunto de que forma parte en una situación determinada; cuando se encuentran ante verbo en forma personal han de incrementarse con que, y toda la oración que introducen pasa a ser el elemento 'excluido': "Lo confesaron todo, excepto-menos-salvo que tú estabas implicado" ${ }^{82}$. En todos estos casos exigen un sintagma que indique el conjunto global o la totalidad al cual relacionan el elemento 'excluido' que ellos introducen. Sin embargo, este elemento puede estar implícito, lo cual suele ocurrir en frases negativas, o cuando el elemento introducido es un circunstancial: «Todo fue bien excepto-menos-salvo el primer día», "No dieron muchos regalos, excepto-salvo a los niños" (aquí menos no parece muy "natural»: en realidad, no lo he podido documentar).

El empleo de estos elementos en tales contextos es antiguo en castellano ${ }^{83}$, con los caracteres ya indicados:

"Esto yo non uos otorgo saluo la fabla de mano" (JRuiz, LBA, 686 a), "Et dexólos a todos muy bien heredados, salvo a vuestro padre" (DJManuel, Libro armas, en Crestom., pág. 392), «...ni otra cosa puedo sentir que fuesse, saluo alteracion que tu me causaste» (Celestina, IX), etc.; o sin elemento anterior: "Ca non es este mundo lleno salvo de tribulaciones e de pena, et non se enbuelve el omne con todo esto salvo en mal desque es conçebido..." (Calila, en Crestom., 211), "Cada que los oyerdes non querades comedir / saluo en la manera del trobar e del

82 Pero con subjuntivo toman valor condicional: «excepto-(a) menos-salvo que tú vengas, no nos iremos»; cfr. J. MONDÉJAR, "La expresión de la condicionalidad en español (conjunciones y locuciones conjuntivas)», RFE, t. XLIX, 1966, págs. 229 254.

83 Por ello extraña que MeYRR-LÜBKe, Grammaire, III, § 138, considere galicismos excepto, incluso, salvo, en español moderno. 
dezir» (JRuiz, LBA, $45 \mathrm{~b}-\mathrm{c}$ ), etc. Con excepto la inmovilización es más tardía: «...se començó a hablar en España la lengua aráviga, ecepto en Asturias, en Vizcaya y Lepuzca» (J. de Valdés, Diálogo Lengua, 57), «...con poca gente y esa concejil, mal pagada (...) excepto los particulares (DHurtado de Mendoza, Guerra, Lib. II),

No obstante, todavía es posible encontrar en los siglos XVI y XVII la concordancia en estos antiguos participios o adjetivos en construcción absoluta ${ }^{84}$; en los textos antiguos es difícil decidir a veces si hay concordancia formal o ya inmovilización:

«...aquel que non quiere aver por su física salvo el gualardón del otro siglo» (Calila, en Crestom., 205), "Et yo non quise ál salvo contender con mi alma" (ibid., 208), «... $\tau$ non le dizen otro nonbre saluo el cavallero del Çisne" (GConqUltramar, I).

En estas construcciones los empleos de las partículas que estamos considerando coexisten con los de la conjunción adversativa sino en su valor 'correctivo' o 'restrictivo'; generalmente exige negación en el primer elemento: "Nadie quiere eso, sino tú»; pero también aparece sin ella: "Todos están consoladísimos, sino ella», "todas escuchaban, sino su señora", sobre todo en español clásico (según Echaide, por contagio de las construcciones con salvo o excepto). Por otro lado, salvo o excepto, cuando el primer elemento es negativo, pueden tomar también sentido 'exclusivo' o 'sustitutivo', al igual que sino, como puede comprobarse en los ejemplos de más arriba. Incluso encontramos a salvo en construcciones 'sustitutivas' propias hoy de sino: «Señor, tales caualleros / non paresçen rregidores, / saluo lobos robadores, / cobdiçiossos, manzilleros» (Villasandino, Cantiga de amores, II, 4 e-h). Y, al revés, salvo que se encuentra con el sentido 'correctivo', próximo a pero, que adoptaba sino que en español medieval y clásico, según Echaide: «Ca sin cuento era grant la caualleria de los moros, pues al de la gente de pie non es quil dar suma podiese, saluo que sierras et campos todo era cobierto de todas partes» (Crón. particular SFernando, c. 1042), "Tenemos todas nuestras bestias muy grandes e muy sazonadas, saluo ende que estan espantadas por el grant tremer de la tierra» (Caballero Cifar, c. 117).

La clasificación de estas partículas también ha sido vacilante y contradictoria (p. ej., el Esbozo, tras haberlas considerado de un tipo especial, vuelve a incluirlas en las conjunciones adversativas en 3.18.8). Dada su equivalencia con sino, y el hecho de que cuando no enlazan

84 LAPESA, «Los casos...», pág. 100. 
el sintagma que introducen con otro parece justificado hablar de elisión de un elemento 'indefinido' (lo mismo ocurre con sino en valor 'sustitutivo': "no quieren sino comida»), parecería lógico incluirlas en las conjunciones adversativas, como han hecho, aunque no de modo unánime, muchos gramáticos desde Bello. Sin embargo, Echaide ha mostrado que estas construcciones presentan el orden típico de la subordinación, por el que pueden anteponerse al elemento con que van enlazados: "todos estaban de acuerdo excepto-salvo-menos unos cuantos»= «excepto-menos-salvo unos cuantos, todos estaban de acuerdo» / * «estaban de acuerdo unos cuantos, excepto-menos-salvo todos» (no permiten, pues, el orden propio de la coordinación). Con sino, al anteponerlo, vuelven a disociarse sus dos elementos y no recupera el acento: "Nadie creerá eso sino tú» $\rightarrow$ "Si no tú, nadie creerá eso». Por ello, habla de que en este caso la construcción con sino es cuasi-preposicional; y considera subordinantes, y por tanto preposiciones, a excepto, salvo y menos. Sin embargo, el valor de estos elementos parece estar más próximo al de una conjunción que al de una preposición, ya que no se ve muy claro qué tipo de relación sintáctico-semántica de subordinación establecen: el sentido de 'no-inclusión' en serie (sin los valores y posibilidades propiamente adverbiales de aun, hasta, incluso) los acerca a las conjunciones, y, por establecer una contraposición, a las adversativas.

Por otro lado hay adverbios que se trasladan a indicar esta simple 'inclusión' o 'exclusión', sin otros valores, de un elemento en una serie: el antiguo fuera(s), foras ('excepto'), o además, amén, etc. indicando 'inclusión'. Cuando lo que enlazan son sintagmas nominales han de llevar de (como otros casos de adverbio con complemento), y si oraciones han de añadir que; fuera $(s)$ prescindía muchas veces de la preposición. Así: «E do uos la mia heredat de Rodelga, e con quanto que hi podiero auer, foras el castiello" (Doc. Ling., n. ${ }^{\circ}$ 262, Cerrato, 1194), «...por fazer della so pro quando mester les fuere, fueras que non sea uedada alos ganados nialas yentes» (ibid., n. ${ }^{\circ} 335$, Andújar, 1235), «...y que, amén de su manía, tuviese una instrucción bastante..." (Jovellanos, Obras, III, 316), "han venido varias personas, además de ti», etc.; parecen ser locuciones preposicionales, pero su valor semántico es simplemente conjuntivo (copulativo o adversativo).

Rafael Cano Aguilar 


\section{RELACION DE FUENTES}

Alemán, Mateo, Guzmán de Alfarache, 5 vols., ed. de Samuel Gili Gaya, Clásicos Castellanos (reimpr.), Madrid, 1968.

Alemany y Selfa, Bernardo, Vocabulario de las obras de Don Luis de Góngora y Argote, R. A. E., Madrid, 1930.

Alfonso X, Primera Crónica General, ed. de R. Menéndez Pidal, Madrid, Ed. Gredos, 1955.

General Estoria, ed. de A. G. Solalinde, Madrid, 1930-1961.

Azorf́, Doña Inés, ed. de Elena Catena, Clásicos Castalia, Madrid, 1973.

Berceo, Gonzalo DE, Vida de San Millán de la Cogolla, ed. de Brian Dutton, London, Tamesis Books Ltd., 1967.

Milagros de Nuestra Señora, ed. de A. G. Solalinde, 7. ed., Clásicos Castellanos, Madrid, 1968.

Vida de Santo Domingo de Silos, ed. de T. Labarta, Clásicos Castalia, Madrid, 1972.

El Duelo de la Virgen. Los himnos. Loores de Nuestra Señura. Signos del juicio final, ed. de Brian Dutton, Tamesis Books Ltd., London, 1975.

Biblia medieval romanceada. I. Pentateuco, ed. de A. Castro, A. Millares Carlo y A. J. Battistessa, Buenos Aires, 1927.

Cadalso, José, Cartas marruecas, ed. de J. Tamayo y Rubio, Clásicos Castellanos, Madrid, 1967.

Noches lúgubres, ed. de Nigel Glendinning, 2.a ed., Clásicos Castellanos, Madrid, 1969.

Cervantes, Miguel DE, El ingenioso hidalgo Don Quijote de la Mancha, 8 vols., ed. de F. Rodríguez Marín, Clásicos Castellanos (reimpr.), Madrid, 1968.

Novelas ejemplares, 2 vols., ed. de F. Rodríguez Marín, Clásicos Castellanos (reimpresión), Madrid, 1969.

Córdoba, Martin Alfonso de, Tractado de la Predestinación, ed. de A. Sánchez Fraile, Salamanca, 1956.

Cuervo, Rufino J., Diccionario de construcción y régimen de la lengua castellana, Bogotá, Instituto Caro y Cuervo, 1953.

Debax, Michelle, Lexique de la Diana de Jorge de Montemayor, Université de Toulouse, 1971.

Feijoo, Benito Jeronimo, Teatro crítico universal, III, ed. de A. Millares Carlo, Clásicos Castellanos, Madrid, 1966.

Fernandez Gómez, Carlos, Vocabulario completo de lope de Vega, 3 vols., R. A. E., Madrid, 1971.

Vocabulario de Cervantes, R. A. E., Madrid, 1962.

Fernández DE Moratin, Leandro, La comedia nueva o El Café. El sí de las niñas, ed. de F. Ruiz Morcuende, Clásicos Castellanos, Madrid, 1968.

Fernandez Santaella, Rodrigo, Vocabularium ecclesiasticum (1499), Madrid, 1770.

Gracián, Baltasar, El Criticón, ed. de M. Romera-Navarro, University of Pennsylvania Press, Philadelphia-London, 1938-1940.

Oráculo manual $y$ arte de prudencia, ed. de M. Romera-Navarro, Anejo LXII de la RFE, Madrid, 1954.

Hurtado de Mendoza, Diego, Guerra de Granada, ed. de B. Blanco-González, Clásicos Castalia, Madrid, 1970. 
Jovellanos, Gaspar Melchor De, Obras, III, ed. de A. del Río, 3.a ed., Clásicos Castellanos, Madrid, 1969.

Keniston, Hayward, The Syntax of Castilian Prose. The Sixteenth Century, The University of Chicago Press, 1937.

Larra, Mariano José DE, Obras, I, ed. de Carlos Seco Serrano, BAE, Madrid, 1960.

Lazarillo de Tormes, ed. de J. Cejador, Clásicos Castellanos (reimpr.), Madrid, 1966.

Libro de Alexandre, ed. de Raymond S. Willis Jr., Krauss Reprint Co., New York, 1965.

Libro de Apolonio, 3 vols., ed. de M. Alvar, Ed. Castalia, 1976.

Machado, ANtonio, Juan de Mairena, ed. de José M.a Valverde, Clásicos Castalia, Madrid, 1971.

Martinez de Toledo, Alfonso, Arcipreste de Talavera o Corbacho, ed. de J. GonzálezMuela, Cásicos Castalia, Madrid, 1970.

Menéndez Pidal, Ramón, Cantar de Mio Cid. Texto, gramática y vocabulario, 4." ed., Madrid, Espasa-Calpe, 1964.

Crestomatía del español medieval, 2 vols., Universidad de Madrid-Facultad de Filosofía y Letras, Seminario Menéndez Pidal, Madrid, 1965.

Documentos lingüisticos de España. I. Reino de Castilla (reimpr.), CSIC, Madrid, 1966.

PéREz de Ayala, RAmón, Las novelas de Urbano y Simona, Alianza Editorial, Madrid, 1973, 2.a ed.

Pérez Galdós, Benito, Lo prohibido, ed. de José F. Montesinos, Clásicos Castalia, Madrid, 1971.

Quevedo, Francisco DE, Los sueños, 2 vols., ed. de J. Cejador, Clásicos Castellanos (reimpr.), Madrid, 1966-1967.

Politica de Dios, Govierno de Christo, ed. de James O. Crosby, Madrid, Ed. Castalia, 1966.

Ruiz, Juan, Libro de Buen Amor, ed. de J. Corominas, Madrid, Ed. Gredos, 1967.

SAN PEdro, Diego DE, Cárcel de Amor, ed. de Keith Whinnon, Clásicos Castalia, Madrid, 1971.

Tragicomedia de Calixto y Melibea. Libro también llamado La Celestina, ed. de M. Criado de Val y G. D. Trotter, CSIC, Madrid, 1965.

Trueba, Antonio DE, Cuentos populares, Madrid, 1924.

Valdés, JuAn DE, Diálogo de la lengua, ed. de J. M. Lope Blanch, Clásicos Castalia, Madrid, 1969.

Valera, Juan, Las ilusiones del Doctor Faustino, ed. de Cyrus C. De Coster, Clásicos Castalia, Madrid, 1970.

ZunzungGUi, JuAN A. DE, Obras completas, II, Barcelona, Ed. Noguer, 1970. 